\title{
Improvement of Wear, Pitting Corrosion Resistance and Repassivation Ability of Mg-Based Alloys Using High Pressure Cold Sprayed (HPCS) Commercially Pure-Titanium Coatings
}

\author{
Mohammadreza Daroonparvar ${ }^{1, *}$, Ashish K. Kasar ${ }^{2}\left(\mathbb{D}\right.$, Mohammad Umar Farooq Khan ${ }^{3}$, Pradeep L. Menezes ${ }^{2, *}$ (1), \\ Charles M. Kay ${ }^{4}$, Manoranjan Misra ${ }^{1}$ and Rajeev K. Gupta ${ }^{3}(\mathbb{D}$ \\ 1 Department of Chemical and Materials Engineering, University of Nevada, Reno, NV 89501, USA; \\ misra49@gmail.com \\ 2 Department of Mechanical Engineering, University of Nevada, Reno, NV 89501, USA; \\ akasar@nevada.unr.edu \\ 3 Department of Materials Science and Engineering, College of Engineering, North Carolina State University, \\ 911 Partners Way, Raleigh, NC 27695, USA; mk189@zips.uakron.edu (M.U.F.K.); rkgupta2@ncsu.edu (R.K.G.) \\ 4 ASB Industries Inc., Barberton, OH 44203, USA; cmkay@asbindustries.com \\ * Correspondence: mr.daroonparvar@yahoo.com (M.D.); pmenezes@unr.edu (P.L.M.)
}

check for

updates

Citation: Daroonparvar, M.; Kasar, A.K.; Farooq Khan, M.U.; L. Menezes, P.; Kay, C.M.; Misra, M.; Gupta, R.K. Improvement of Wear, Pitting Corrosion Resistance and Repassivation Ability of Mg-Based Alloys Using High Pressure Cold Sprayed (HPCS) Commercially Pure-Titanium Coatings. Coatings 2021, 11, 57. https://doi.org/ 10.3390/coatings 11010057

Received: 16 December 2020 Accepted: 28 December 2020 Published: 6 January 2021

Publisher's Note: MDPI stays neutral with regard to jurisdictional clai$\mathrm{ms}$ in published maps and institutional affiliations.

Copyright: (C) 2021 by the authors. Licensee MDPI, Basel, Switzerland. This article is an open access article distributed under the terms and conditions of the Creative Commons Attribution (CC BY) license (https:// creativecommons.org/licenses/by/ $4.0 /)$.

\begin{abstract}
In this study, a compact cold sprayed (CS) Ti coating was deposited on Mg alloy using a high pressure cold spray (HPCS) system. The wear and corrosion behavior of the CS Ti coating was compared with that of CS Al coating and bare Mg alloy. The Ti coating yielded lower wear rate compared to $\mathrm{Al}$ coating and $\mathrm{Mg}$ alloy. Electrochemical impedance spectroscopy (EIS) and cyclic potentiodynamic polarization (CPP) tests revealed that CS Ti coating can substantially reduce corrosion rate of AZ31B in chloride containing solutions compared to CS Al coating. Interestingly, Ti-coated $\mathrm{Mg}$ alloy demonstrated negative hysteresis loop, depicting repassivation of pits, in contrast to AZ31B and $\mathrm{Al}$-coated $\mathrm{AZ31B}$ with positive hysteresis loops where corrosion potential $\left(E_{\mathrm{corr}}\right)>$ repassivation potential $\left(E_{\mathrm{rp}}\right)$; indicating irreversible growth of pits. AZ31B and Al-coated AZ31B were most susceptible to pitting corrosion, while Ti-coated $\mathrm{Mg}$ alloy indicated noticeable resistance to pitting in $3.5 \mathrm{wt} \% \mathrm{NaCl}$ solution. In comparison to $\mathrm{Al}$ coating, Ti coating considerably separated the $\mathrm{AZ} 31 \mathrm{BMg}$ alloy surface from the corrosive electrolyte during long term immersion test for 11 days.
\end{abstract}

Keywords: Ti coating; cyclic potentiodynamic polarization (CPP) test; hysteresis loop; wear

\section{Introduction}

Magnesium (Mg) and its alloys (with a low density of about $1.8 \mathrm{~g} / \mathrm{cm}^{3}$ ) have become a hot topic of research because of the potential engineering applications. Moreover, magnesium alloys show outstanding potential in automotive, aerospace, and electronic industries because of their high strength-to-weight ratio, high stiffness, outstanding electromagnetic shielding ability, and remarkable damping performance, etc. In recent years, $\mathrm{Mg}$ alloys have been receiving ascending attention as biodegradable implant materials, as well. Regrettably, the inferior wear and corrosion performances of $\mathrm{Mg}$ alloys severely limit their extensive applications. The most commonly employed method for improving the surface properties of a substrate is surface treatment. In this regard, various conversion coatings [1], anodization process, plasma electrolytic oxidation (PEO), physical vapor deposition (PVD), electro-less, before processes: annealing processes, electroplating and ions implantation methods and thermal spray processes have been employed to modify the surface of $\mathrm{Mg}$ alloys for improving their wear and corrosion resistances [2-10].

An approximate new coating technology that deserves particular attention is cold spray process (as an environmentally friendly method) which doesn't involve toxic fumes or other harmful emissions [11,12]. Compared to the high velocity oxy-fuel (HVOF) thermal spray process which uses a combination of thermal and kinetic energies, cold spray 
utilizes only kinetic (dynamic) energy to deposit the powder particles [12-15]. Likewise, the microstructural degeneration of heat-susceptible substrates such as $\mathrm{Mg}$ alloys which is frequently seen in the substitute thermal spray methods could be prevented by means of cold spray process [4,16-18]. In contrast to thermal spray technologies such as electric arc wire spray, plasma spray, flame spray and HVOF spray processes which partially and/or fully melt particles during the spray process; CS can avert the thermal effects including oxidation, porosity, grain growth and phase transformation during spray process $[12,13,19,20]$.

It was reported that corrosion resistance of $\mathrm{Mg}$ alloys can be improved with the cold sprayed coatings (in comparison with counterpart coatings made by other techniques e.g., anodizing, E-plating, conversion coating and etc.), in $3.5 \mathrm{wt} \% \mathrm{NaCl}$ solution [21]. Aluminum (with good corrosion resistance, low density, and having low standard electrode potential difference with $\mathrm{Mg}$ alloys) is used (as protective coating) to reduce the corrosion rate of $\mathrm{Mg}$ substrates [2,22-24]. Current cold sprayed ( $\mathrm{N}_{2}$ as propellant gas) Al-based coatings (as single layer) on $\mathrm{Mg}$ alloys lack acceptable hardness, wear resistance and are highly susceptible to localized corrosions in severe corrosive atmospheres $[22,25,26]$. These coatings also showed low repassivation ability [27]. In fact, the passive film has a weak propensity to repair itself (or passivate) in corrosive environment.

Compared to $\mathrm{Al}$ and its alloys, $\mathrm{Ti}$ and its alloys can be extensively used in severe corrosive environments such as offshore (salt water), aerospace, automotive, etc. This was attributed to the good mechanical properties and excellent corrosion resistance (due to the formation of a firm protective oxide film on the metal surface) [28-30]. Low standard reduction potential mismatch between coating and substrate makes Ti coating (from group 4B) as a subsequent candidate for the corrosion protection of $\mathrm{Mg}$ and its alloys [31,32]. In this regard, warm sprayed (WS) Ti coatings couldn't noticeably enhance the corrosion potential and lower the corrosion current density of AZ91E Mg alloy [31]. These coatings disclosed poor corrosion resistance and finally led to the fast degeneration of $\mathrm{Mg}$ alloy. The poor performance of WS Ti coatings was due to the presence of through-thickness porosities which simply conducted the chloride containing solution towards the substrate surface. The untimely tear of titanium coatings (after only $24 \mathrm{~h}$ of immersion) in $3.5 \mathrm{wt} \% \mathrm{NaCl}$ electrolyte was eventually observed [31]. This was mainly related to the corrosion products formation and accumulation at the interface between WS Ti coating and Mg substrate [31]. The MS (magnetron sputtered) Ti-coated AZ91D Mg alloy showed even much inferior performance than the uncoated AZ91D Mg alloy after 1 day in $\mathrm{NaCl}$ solution [32]. Most part of MS Ti coatings came off the Mg alloy substrate which had undergone the severe corrosion [32].

In this research, we developed a fairly compact cold sprayed titanium coating on $\mathrm{Mg}$ alloy using HPCS system. It is anticipated that high pressure cold sprayed commercially pure-Ti coating could alleviate the problems associated with current cold sprayed Al coatings on $\mathrm{Mg}$ alloys and exceptionally increase the repassivation ability of $\mathrm{Mg}$ alloys. Moreover, immersion test for 11 days was performed to further elucidate the effectiveness and corrosion protection performance of HPCS titanium coating on magnesium alloys in corrosive environment.

\section{Experimental Methods}

\subsection{Feedstock Powders and Substrate}

In this research, commercially pure $(\mathrm{CP}) \mathrm{Al}$, and $\mathrm{CP}$-Ti grade 1 powders (as feedstock powders) were employed for coating production. Commercially available AZ31B Mg alloy plate $(381 \mathrm{~mm} \times 455 \mathrm{~mm} \times 9.5 \mathrm{~mm})$ was procured from Magnesium EleKtronNorth America. The substrates were then cut from this plate. Table 1 shows the chemical composition of AZ31B Mg alloy. The substrate surface was grit blasted and then cleaned with alcohol and acetone using a hand spray bottle and $\mathrm{N}_{2}$ blow off right before cold spray process. 
Table 1. Chemical composition of AZ31B (wt \%).

\begin{tabular}{ccccccccccc}
\hline Alloy Name & Mg & Al & Zn & Si & Mn & Fe & Cu & Ca & Ni & C \\
\hline AZ31B Mg alloy & Balance & 2.8 & 1.1 & $<0.08$ & 0.7 & $<0.01$ & $<0.01$ & $<0.03$ & $<0.001$ & - \\
\hline
\end{tabular}

\subsection{CS Deposition}

In this research, high pressure cold spray system (Impact Innovation 5/11 system, $\mathrm{GmbH}$,) was used to produce metallic layers on AZ31BMg substrates. The temperature of substrate and coatings was maintained less than $65^{\circ} \mathrm{C}$ during cold spray process. Likewise, Table 2 displays the cold spray parameters. The following coatings were sprayed on the AZ31B Mg alloy:

1. CS Al coating on AZ31B Mg.

2. CS Ti coating on AZ31B Mg.

Table 2. CS process parameters.

\begin{tabular}{ccccccccc}
\hline $\begin{array}{c}\text { Propellant } \\
\text { Gas }\end{array}$ & $\begin{array}{c}\text { Sprayed } \\
\text { Material }\end{array}$ & $\begin{array}{c}\text { Temperature } \\
\left(\mathbf{C}^{\circ}\right)\end{array}$ & $\begin{array}{c}\text { Gas } \\
\text { Pressure } \\
(\mathbf{M P a})\end{array}$ & $\begin{array}{c}\text { Spray Angle } \\
\left(\mathbf{(}^{\circ}\right)\end{array}$ & $\begin{array}{c}\text { Stand-Off } \\
\text { Distance } \\
(\mathbf{m m})\end{array}$ & $\begin{array}{c}\text { Step } \\
\text { Size } \\
(\mathbf{m m})\end{array}$ & $\begin{array}{c}\text { Powder } \\
\text { Feed Rate } \\
(\mathbf{R P M})\end{array}$ & $\begin{array}{c}\text { Powder Carrier } \\
\text { Gas Flow Rate } \\
\left(\mathbf{m}^{\mathbf{3}} / \mathbf{h r}\right)\end{array}$ \\
\hline $\mathrm{N}_{2}$ & $\mathrm{CP}-\mathrm{Al}$ & $350-600$ & $3.0-5.0$ & $90^{\circ}$ & 25.4 & 0.508 & $2.0-3.5$ & 3.0 \\
$\mathrm{~N}_{2}$ & $\mathrm{CP}-\mathrm{Ti}$ & $700-1050$ & $3.0-5.0$ & $90^{\circ}$ & 25.4 & 1.016 & $2.0-3.5$ & 3.0 \\
\hline
\end{tabular}

\subsection{Characterization}

Optical microscopy (IX70, Olympus) was used to analyze the polished cross-sectional microstructures of as-sprayed coatings on the AZ31B. For this purpose, coated AZ31B samples were cut, mounted and polished using with standard metallographic procedures on an Allied Metprep $3^{\mathrm{TM}}$ grinder/polisher system. ImageJ software was utilized to analyze the porosity level of the as-sprayed coatings (using ASTM E2109-01) [33]. The surface morphology, polished cross-sectional microstructures and chemical composition (elemental analysis) of developed coatings before and after immersion test were studied using a LYRA-3 model XUM integrated variable pressure focused ion beam-field emission scanning electron microscope (FIB-FESEM; TESCAN), and a TM-3030 Scanning Electron Microscope (SEM; Hitachi,) equipped with Energy Dispersive X-ray spectroscopy (EDS) capability. Moreover, the structural phases of as-sprayed coatings, bare AZ31B Mg alloy substrate and feed stock powders were analyzed using an Ultima IV X-ray machine (Rigaku), after grinding up to 1200 grit size sandpaper (for only bare and coated Mg alloys). The $\mathrm{X}$-ray tube emits $\mathrm{Cu}-\mathrm{K} \alpha$ radiation with an excitation voltage of $40 \mathrm{kV}$ and excitation current of $35 \mathrm{~mA}$. The samples were scanned at a rate of 1 degree/min with a step width of 0.04 degree. The data were analyzed using $X^{\prime}$ Pert HighScore Plus software with ICDD database. Furthermore, $2 \theta$ (as diffraction angle) range of $30^{\circ}-90^{\circ}$ was employed to collect diffraction patterns of the different samples.

A Vickers hardness tester (Beuhler-Wilson Tukon 1202), was used to measure the microhardnesses of the substrate and the coatings, under the load of $0.245 \mathrm{~N}$. It should be noted that the substrate hardness measurements were performed at the regions away from the interface between coating and the $\mathrm{Mg}$ alloy substrate. Additionally, ten (10) measurements were done on each sample and the average was reported as micro-hardness value.

Average surface roughness $\left(R_{\mathrm{a}}\right)$ of as-cold sprayed coatings were inspected during profilometry using an Alicona Infinite Focus, a 3D measurement system which has a noncontact, optical measurement principle based on focus-variation. Prior to profilometry, the surface was cleaned with DI water using an ultrasonic cleaner. The brightness and contrast were adjusted at a range of focus to make sure all the features are within focus during the scan. The lateral resolution was set at $50 \mathrm{~nm}$. $R_{\mathrm{a}}$ was measured using line scans across the IFM scan. At least five readings were collected for $R_{\mathrm{a}}$ to minimize standard deviation.

Dry reciprocating sliding tests (according to ASTM G133-05 [34]) were performed using a Rtech-Tribometer at room temperature $\left(\sim 25^{\circ} \mathrm{C}\right.$ and $40-50 \%$ relative humidity). 
Prior to sliding tests, all the coated surfaces were polished to achieve an average surface roughness $\left(R_{a}\right)$ of $0.2 \pm 0.05 \mu \mathrm{m} . R_{\mathrm{a}}$ is defined as the arithmetic mean of the absolute values of the vertical deviation from the mean line through the profile [35]. E52100 steel ball with $6.35 \mathrm{~mm}$ diameter was used as a counterpart. All the reciprocating sliding tests were carried out with a track length of $15 \mathrm{~mm}$ and $1 \mathrm{~mm} / \mathrm{s}$ velocity under a normal load of $4 \mathrm{~N}$ for a total distance of $1000 \mathrm{~mm}$. The $1000 \mathrm{~mm}$ of sliding distance was selected based on the stabilized wear depth during sliding. The wear depth was recorded to measure the wear volume. The specific wear rate was then measured using the following formula [36]:

$$
\text { Wear rate }\left(\mu \mathrm{m}^{3} / \mathrm{Nm}\right)=\frac{\text { Wear volume }\left(\mu \mathrm{m}^{3}\right)}{\text { Normal load }(\mathrm{N}) \times \text { Sliding distance }(\mathrm{m})}
$$

\subsection{Sample Preparation for Corrosion Tests}

The surface area of as-cold sprayed coatings which have a highly active surface [37] is increased. This is attributed to the rough surface of as-cold sprayed coatings. As a general practice, the rough and porous surface layer of as-cold sprayed coatings should be removed before corrosion tests [28]. Hence, the samples surface was ground up to 1200 US grit size sandpaper ( $\mathrm{SiC}$ abrasive papers) and then cleaned with ethanol using an ultrasonic cleaner for 5 min before cyclic potentiodynamic polarization (CPP), electrochemical impedance spectroscopy (EIS) and long term immersion tests.

\subsection{Cyclic Potentiodynamic Polarization (CPP) Tests in 3.5 wt \% NaCl Solution}

Cyclic potentiodynamic polarization tests were performed in a three-electrode setup using a flat cell and a Bio-logic potentiostat (per ASTM standard G61 [38]). The standard calomel electrode, platinum electrode, and sample under test were connected as a reference electrode, counter electrode, and working electrode, respectively. Before the CPP test, the open circuit potential (OCP) was tracked for $1 \mathrm{~h}$ to allow the system to achieve an equilibrium in the electrolyte. PDP tests were done in $3.5 \mathrm{wt} \% \mathrm{NaCl}(\mathrm{pH} 6.7)$ at a scan rate of $1 \mathrm{mV} / \mathrm{s}$ from $200 \mathrm{mV}$ below OCP to a current limit of $10 \mathrm{~mA} / \mathrm{cm}^{2}$ or a potential limit of $2.5 \mathrm{~V}_{\mathrm{SCE}}$ and reversed back to the same starting potential of $200 \mathrm{mV}$ below OCP at room temperature. The pitting potential was determined by intersecting the line coming from extending the passive current density region and the linear increase in the current density region after passivation region.

\subsection{Electrochemical Impedance Spectroscopy (EIS) in 3.5 wt \% $\mathrm{NaCl}$ Solution}

A three-electrode setup was used in a flat cell where standard calomel electrode, platinum electrode, and sample were connected as a reference electrode, counter electrode, and working electrode, respectively. The sample was monitored for $1 \mathrm{~h}$ observing the OCP in $3.5 \% \mathrm{NaCl}$ ( $\mathrm{pH}$ 6.7) exposing an area of $1 \mathrm{~cm}^{2}$ at room temperature. Likewise, $100 \mathrm{kHz}$ to $10 \mathrm{mHz}$ (as frequency range) at OCP was selected for performing EIS test. For each EIS scan, ten measurements were recorded per decade, with an average of at least three points per measurement. Furthermore, sinusoidal AC perturbation with an amplitude of $10 \mathrm{mV}$ (rms) was considered for all EIS tests. EC-lab 11.21 provided in the Bio-logic potentiostat was utilized to analyze CPP as well as the EIS data. Electrochemical corrosion tests were carried out three times to substantiate the repeatability of the obtained results. After the immersion test for 11 days, the samples were rinsed with DI water and subsequently dried in air.

\section{Results and Discussion}

\subsection{Powders Morphology and Coatings Microstructure}

$\mathrm{CP}$ (commercially pure)-Al (in the size range of 9-40 $\mu \mathrm{m}$ ), and CP-Ti (in the size range of 10-45 $\mu \mathrm{m}$ ) powders all possess spherical morphology as shown in Figure 1a,b respectively. Surface morphology of CS Ti and Al coatings (in as-sprayed condition) is shown in Figure $2 \mathrm{~b}, \mathrm{~d}$, respectively. $R_{\mathrm{a}}$ of coatings (in as-sprayed condition) was $2.816 \pm 0.7 \mu \mathrm{m}$ and 
$2.182 \pm 0.7 \mu \mathrm{m}$ for $\mathrm{Al}$ and Ti coatings, respectively. Lower $R_{\mathrm{a}}$ for Ti coating was due to intense plastic deformation of Ti particles during CS process. Figures 2a,c and 3 demonstrate the microstructure of polished cross section of the coatings on the AZ31B substrate.
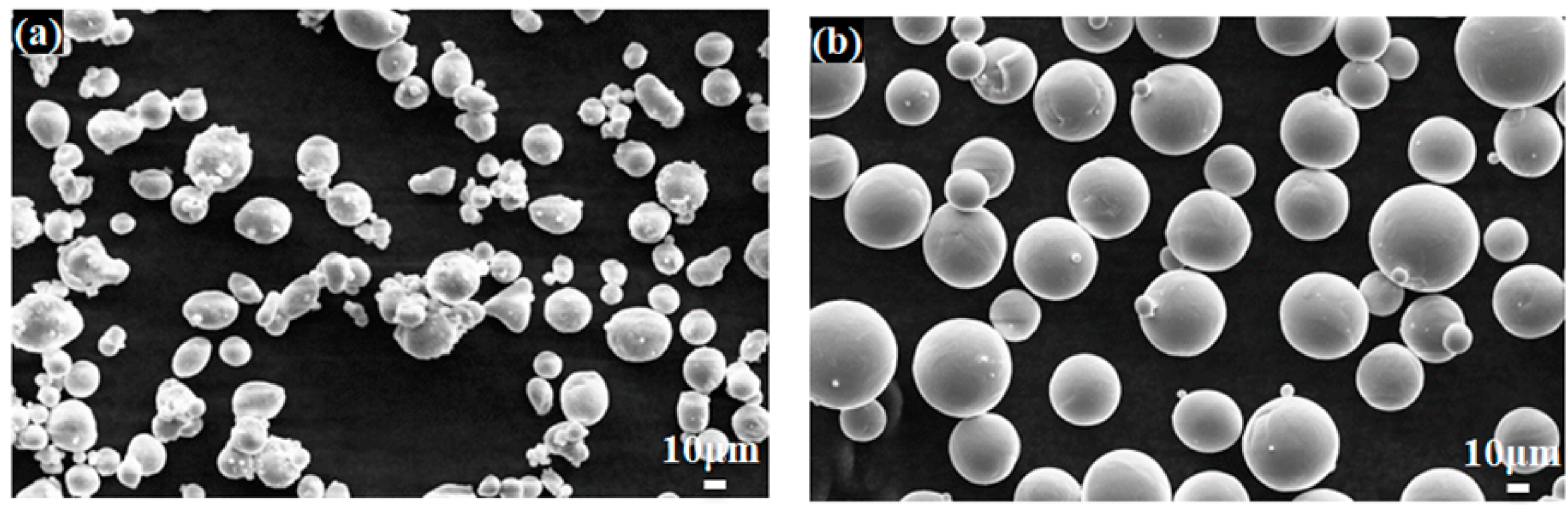

Figure 1. SEM images of feedstock powders (a) commercially pure-Al, and (b) commercially pure-Ti powders.

The local deformation of Ti powder particles was obvious (Figure 3c-e). Moreover, relatively dense microstructure (Figure $3 a, b$ and Figure $2 a$ ) along with very limited micropores with porosity level of about $0.40 \pm 0.20 \%$ was observed for titanium coating (in this research work). On the contrary, higher level of porosities were detected in atmospheric plasma sprayed (APS) Ti coating (with 10.2\% porosity level) and CS Ti coating (with $2.7 \%$ porosity level) as well [31,39]. Different thermal spray methods have been employed to deposit Ti coatings with low level of porosities and high purity as well. However, thermal degradation of the deposited Ti powder particle occurs during HVOF spray process. This could be related to the temperature range of spray powder particles which is about $1227-2427^{\circ} \mathrm{C}$. In fact, the probability of a hard and brittle oxygen enriched layer formation (in the case of $\mathrm{Ti}$ ) which is also known as " $\alpha$-case" is expected and could cause the notable loss of plasticity, ductility, etc. [31]. Another method is LPPS (low pressure plasma spray) process that could restrict oxidation during spray process. This is attributed to the vacuum environment which makes this technique costly. Instead, in warm spray (as modification of HVOF spray system [31]) method, supersonic gas flow temperature is adjusted by injecting $\mathrm{N}_{2}$ into the mixing chamber. Formation of a relatively dense coating with limited oxidation of powder particles is anticipated using this method. Nevertheless, higher level of porosities was reported in the deposited Ti coatings (with porosity level of about $3.8-5.5 \%$ ) on $\mathrm{Mg}$ alloys by WS method under different $\mathrm{N}_{2}$ flow rates $[31,39]$. Higher level of porosities in warm sprayed Ti coatings substantially declined their corrosion resistance in $3.5 \mathrm{wt} \% \mathrm{NaCl}$ solution and caused quick degradation of $\mathrm{Mg}$ substrate during long term corrosion (after $24 \mathrm{~h}$ of immersion) [31].
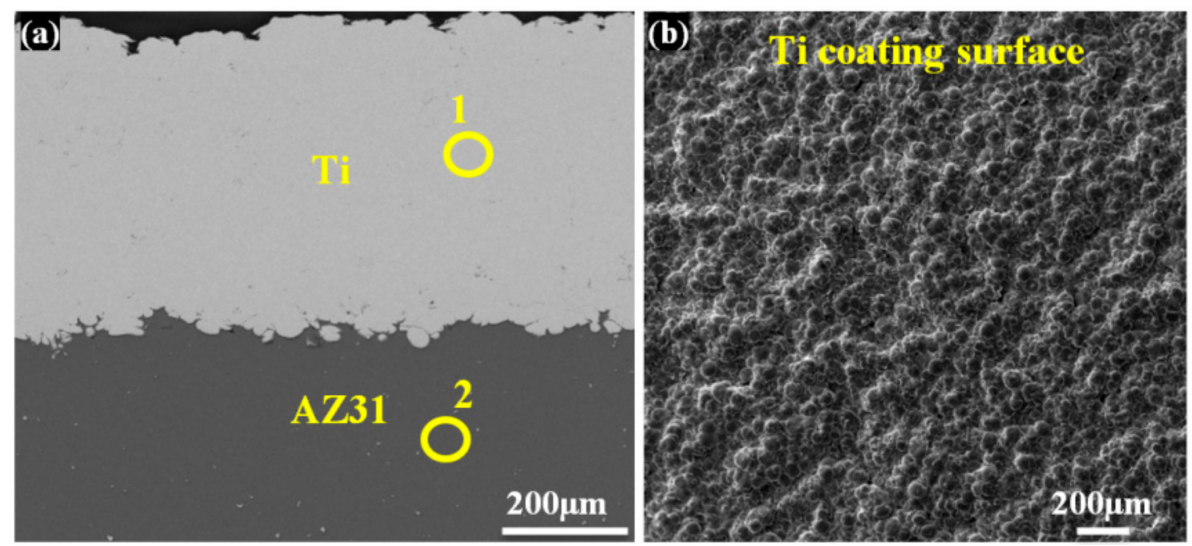

Figure 2. Cont. 

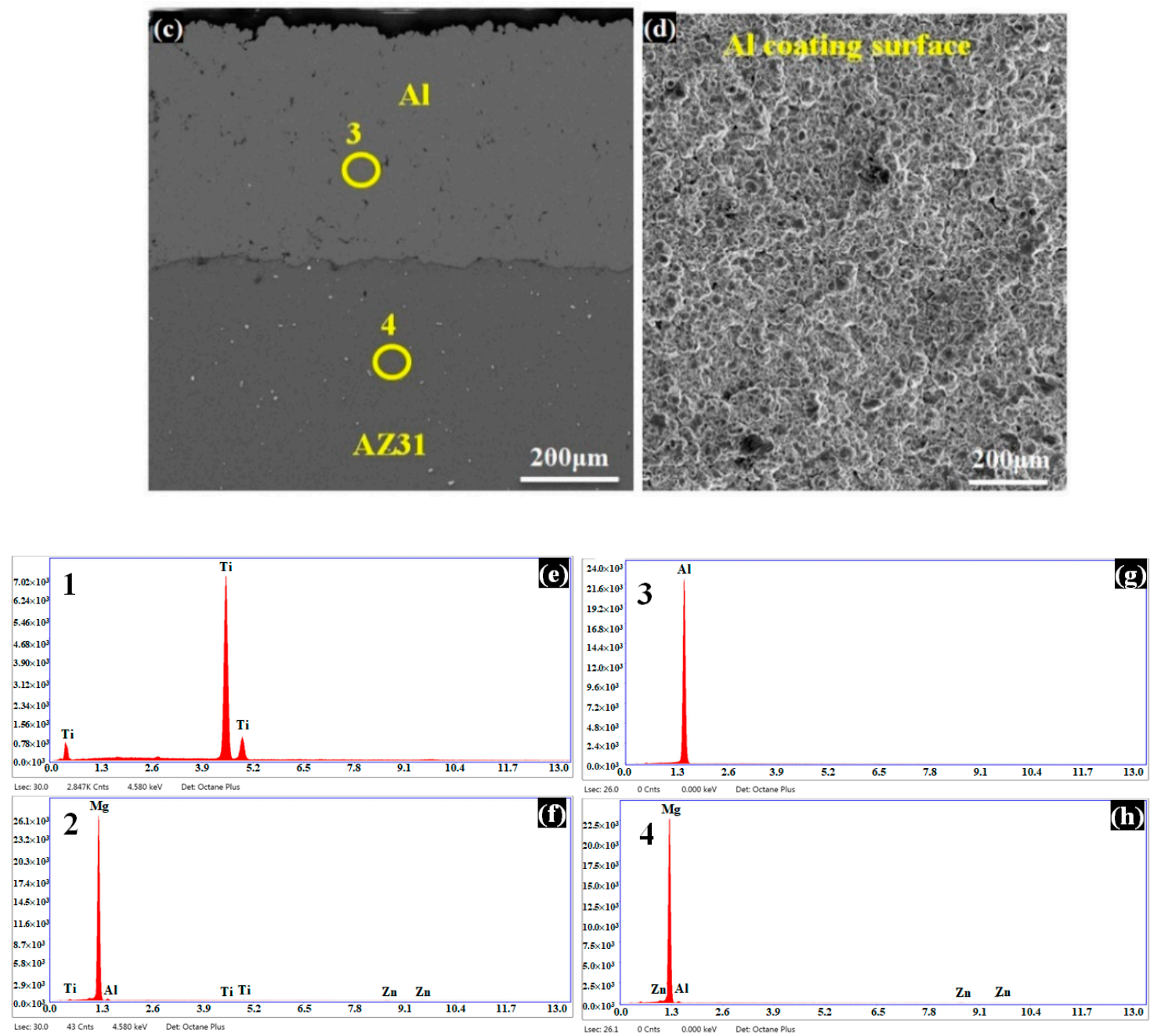

Figure 2. SEM images from (a) cross section of Ti-coated AZ31B, (b) Ti coating surface, (c) cross section of Al-coated AZ31B, (d) Al coating surface, EDS analysis of 1 (e), 2 (f), and EDS analysis of 3 (g), 4 (h).
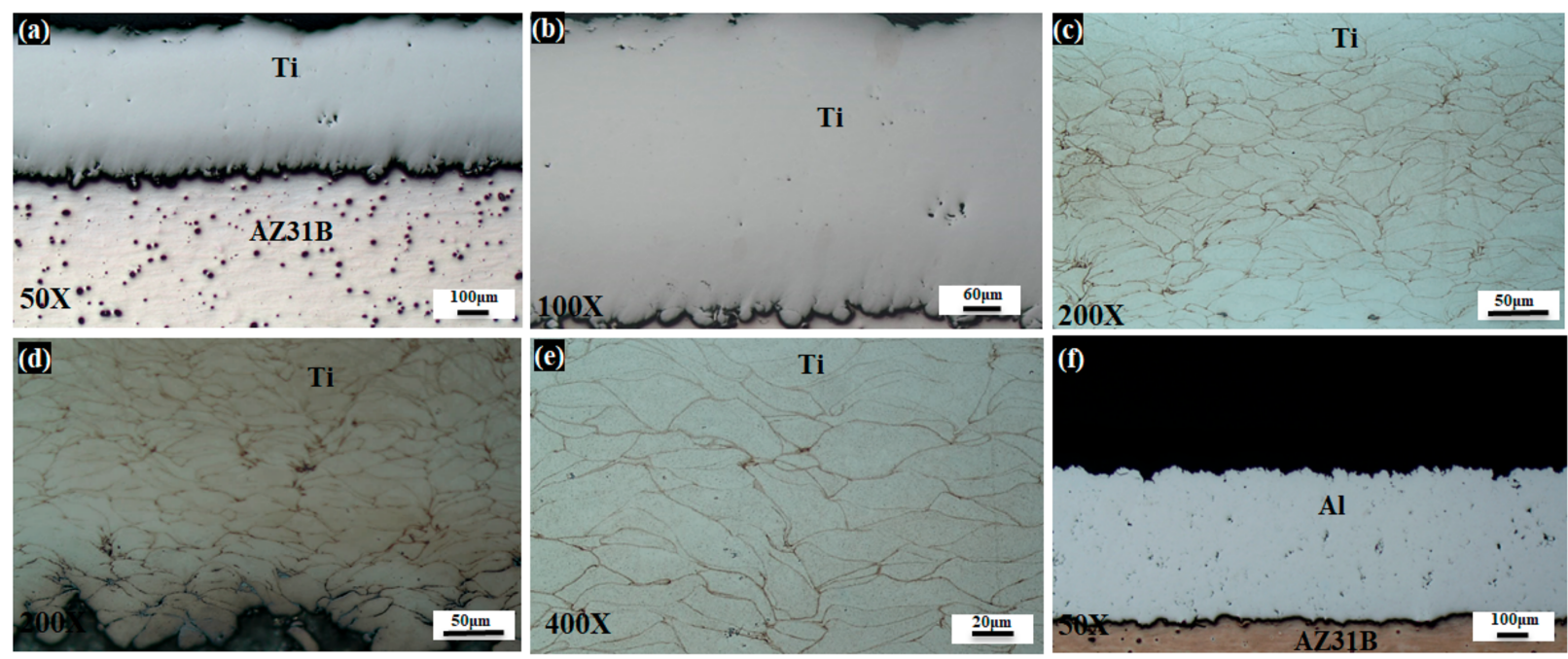

Figure 3. Cont. 

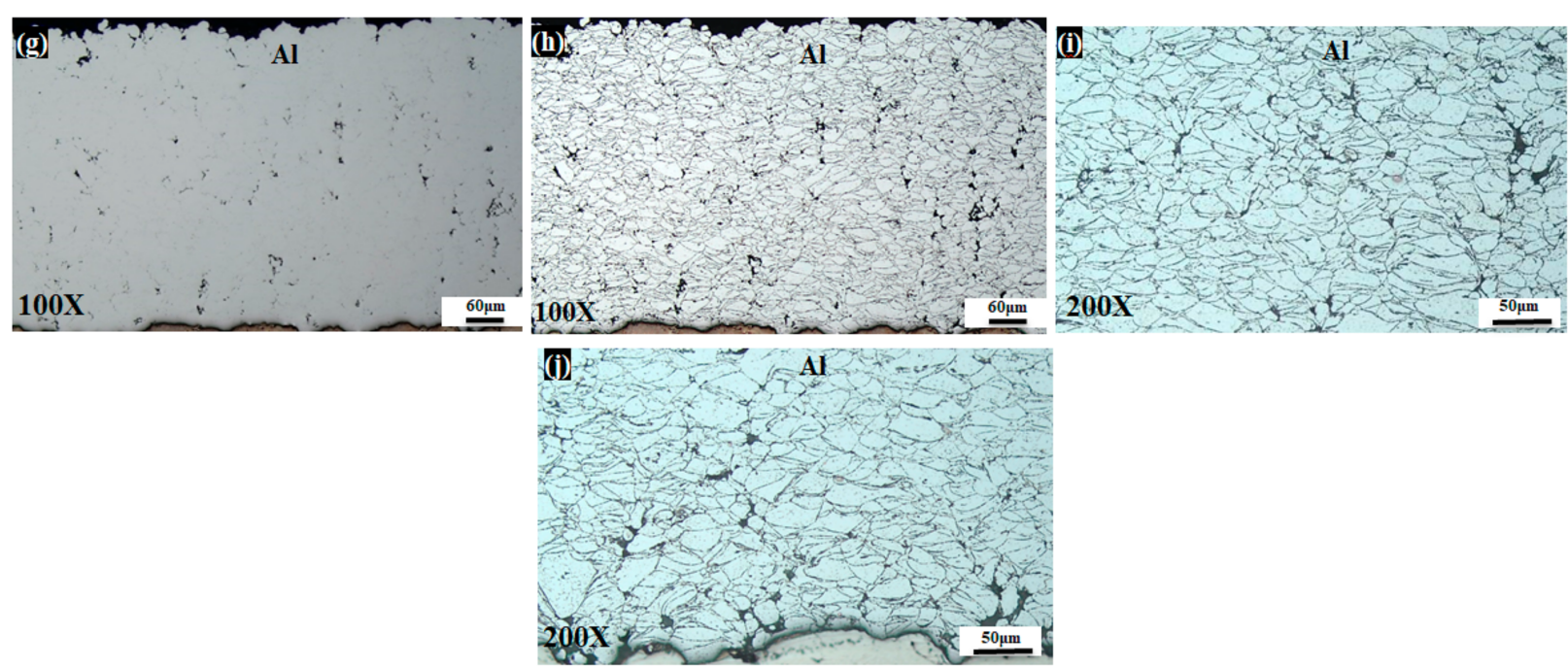

\section{$200 \mathrm{X}$}

Figure 3. Photomicrographs from polished crossed section of (a-e) Ti-coated AZ31B at different magnifications, and (f-j) Al-coated AZ31B at different magnifications before and after etching.

In this study, CP-Al coating with porosity level of about $1.00 \pm 0.20 \%$ depicted higher porosity level than as-sprayed Ti coatings (Figure $3 \mathrm{f}-\mathrm{j}$ ). The presence of considerable number of micro-pores and even (worse) micro-cracks in cold sprayed $\mathrm{CP}-\mathrm{Al}$ coating microstructure (at inter-particle boundaries) on AZ91D Mg alloy was also reported by Y. Tao, et al. [22]. In fact, lower degree of localized plastic deformation (localized heating, stresses) [22] resulted in an extensive formation of micro-defects at inter-particle boundaries. Cold sprayed $\mathrm{Al}$ coating with high denseness and having sub-micron sized grains considerably improved the corrosion resistance compared to CP-Al bulk substrates [22,25].

Figure 4 shows the XRD spectra of bare Mg alloy, feedstock powders and as-cold sprayed coatings. XRD spectrum (Figure 4a) shows that bare AZ31B is mostly comprised of $\alpha-\mathrm{Mg}$ phase. Powder particles and CS coatings displayed similar phase structure and crystal planes (Figure $4 b, c$ ). Phase transformation and oxidation weren't evidently observed in the CS coatings (Figure $4 b, c$ ). The broadened peaks in the XRD pattern of Ti (Figure 4c) coating are primarily related to the intense plastic deformation of powder particles in the coatings compared to $\mathrm{Al}$ coating (Figure $4 \mathrm{~b}$ ) during cold spray process $[40,41]$. Low processing temperature and sizable peening effect of the powder particles (during cold spray process) could lead to the retention of primary phase and crystal planes of powder particles in CS coatings. On the contrary, wire flamed sprayed Ti coatings were mainly constituted by oxides, nitrides, and carbides phases due to the nature of the flame spray process. This resulted in the inferior corrosion protection performance of the sprayed Ti coatings. Hence, these coatings had to be sealed with epoxy or Si resin for usage in the chloride containing solutions [31], so it is anticipated that a Ti coating (in this research) without any post-spray treatments could significantly decrease the corrosion rate of magnesium alloy and make AZ31B Mg alloy usable in chloride containing solutions for long periods of time.

Titanium coating considerably raised average micro-hardness $\left(\mathrm{HV}_{0.025}\right)$ of $\mathrm{AZ31B}$ $\mathrm{Mg}$ alloy surface (Figure 5a), while aluminum coating lowered average micro-hardness $\left(\mathrm{HV}_{0.025}\right)$ of substrate surface (Figure $\left.5 \mathrm{a}\right)$. Higher micro-hardness in Ti coating may implies severe plastic deformation (high dislocation density) mostly at exterior region of powder particles (or inter-particle boundaries) that caused the increase in the coating denseness [13,25]. 


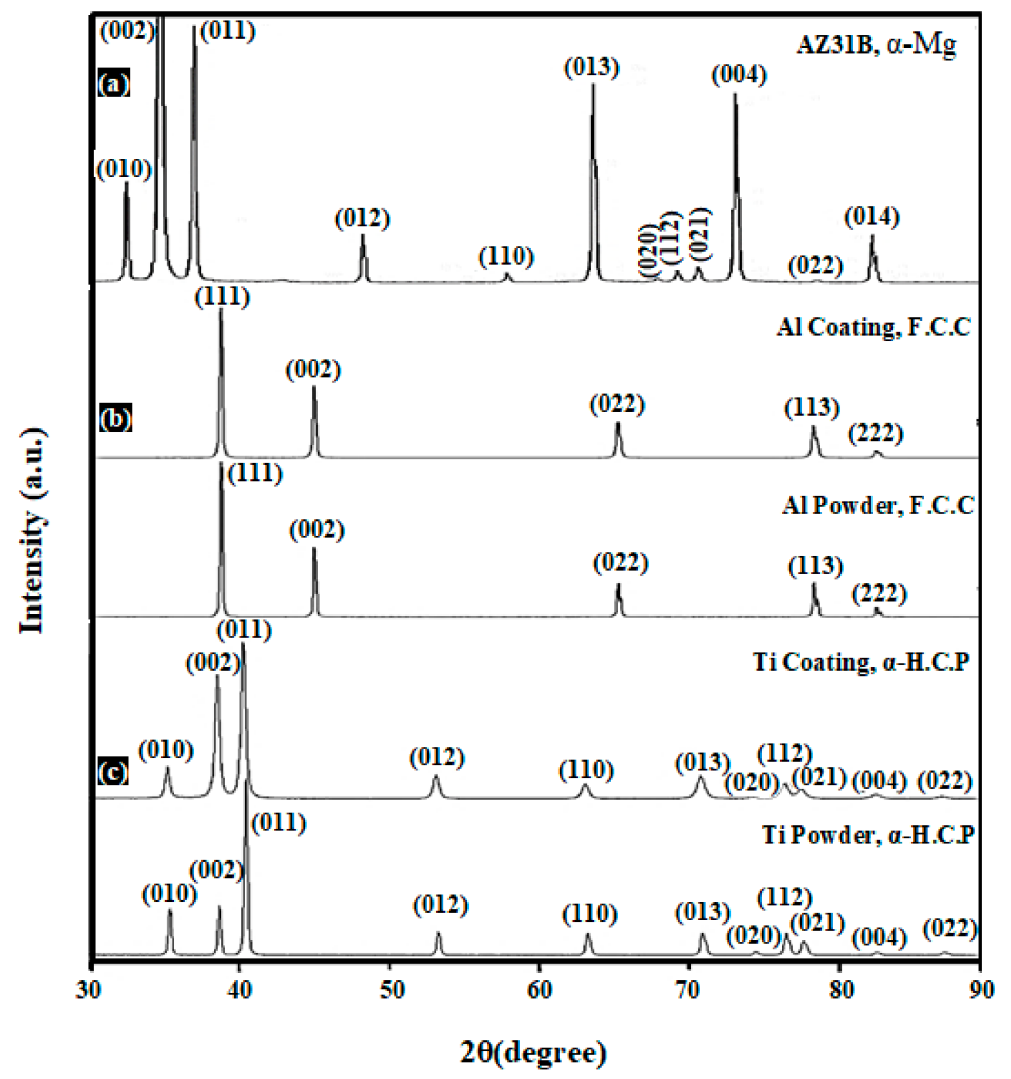

Figure 4. XRD patterns of (a) bare AZ31B, (b) as-received $\mathrm{Al}$ powder particles and as-sprayed $\mathrm{Al}$ coating, and (c) as-received Ti powder particles and as-sprayed Ti coating.

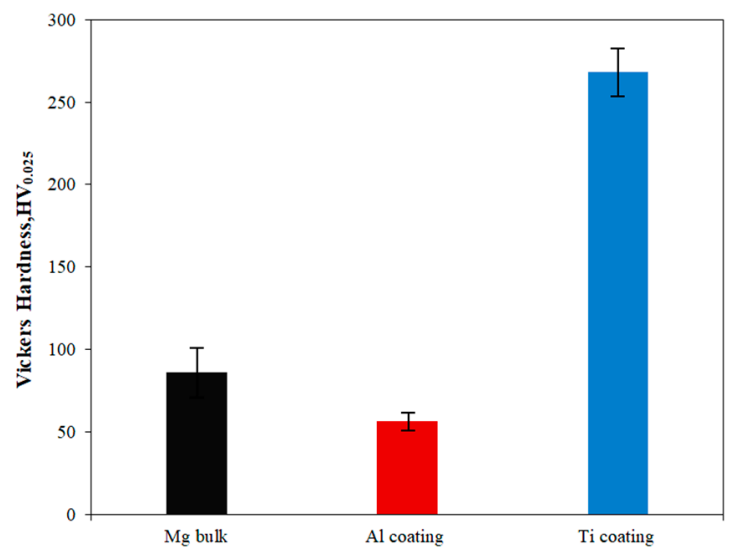

(a)

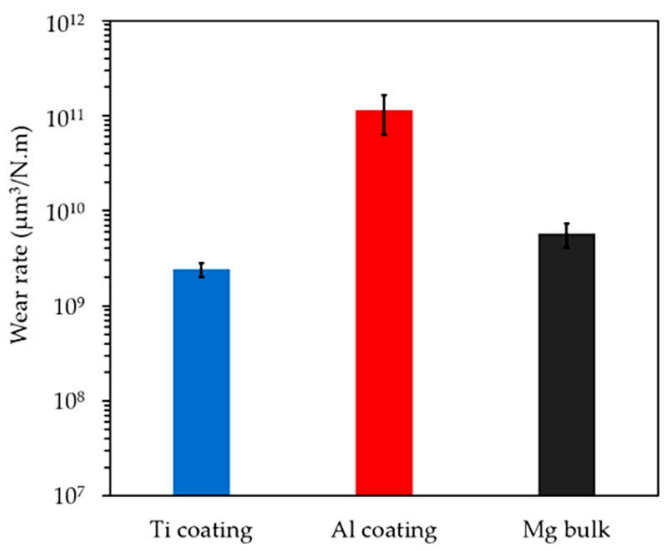

(b)

Figure 5. (a) Average micro-hardness $\left(\mathrm{HV}_{0.025}\right)$; and (b) wear rate of bare and coated $\mathrm{AZ} 31 \mathrm{~B} \mathrm{Mg}$ substrates.

The wear depth on Ti-coated Mg alloy was around $7 \mu \mathrm{m}$ in which Ti surface was in contact with the steel ball whereas the Al-coated $\mathrm{Mg}$ alloy displayed the highest wear depth of $\sim 70 \mu \mathrm{m}$. The wear rate of the entire track calculated from the wear depth was plotted in Figure 5b. These results were also compared with bare AZ31BMg alloy samples that showed lower wear rate compared to Al coating surface but higher wear rate than $\mathrm{Ti}$ coating surfaces. In fact, a surface with higher hardness showed lower wear rate than a surface with lower hardness. This proves that CS Ti coating substantially raises surface hardness and lowers the wear rate of $\mathrm{Mg}$ alloys compared to CS Al coatings. 
The mechanical and tribological characteristics of CS pure Ti coatings on Ti-6Al-4V substrates were studied by Khun et al. [36]. The results indicated that wear resistance of the CS Ti coating (experimented against steel balls) was noticeably higher than that of Ti-6Al-4V alloy. This was related to the cold work hardening (strain hardening) during spray process and interestingly highly wear-resistant oxide layers formation on wear tracks of CS Ti coatings (during wear tests). In fact, cold sprayed pure Ti coatings with higher compactness and lower porosities showed higher hardness and thus improved wear resistance on the Ti64 alloy as substrate [36]. Astarita, et al. also reported that CS Ti coatings can improve the wear performance of bare AA2024 alloy [42].

\subsection{Electrochemical Behavior}

\subsubsection{Cyclic Potentiodynamic Polarization (CPP)}

From the open circuit plots (Figure 6a) it can be seen that the surface of the samples was quite stable over the period of $1 \mathrm{~h}$. The OCP values increase in the order: AZ31B < Al-coated AZ31B < Ti-coated AZ31B. It is evidently seen that bare Mg alloys with lower values of OCP are more susceptible to corrosion compared to coated $\mathrm{Mg}$ samples which showed higher values of OCP. But, Al-coated AZ31B is more active than Ti coated AZ31B.
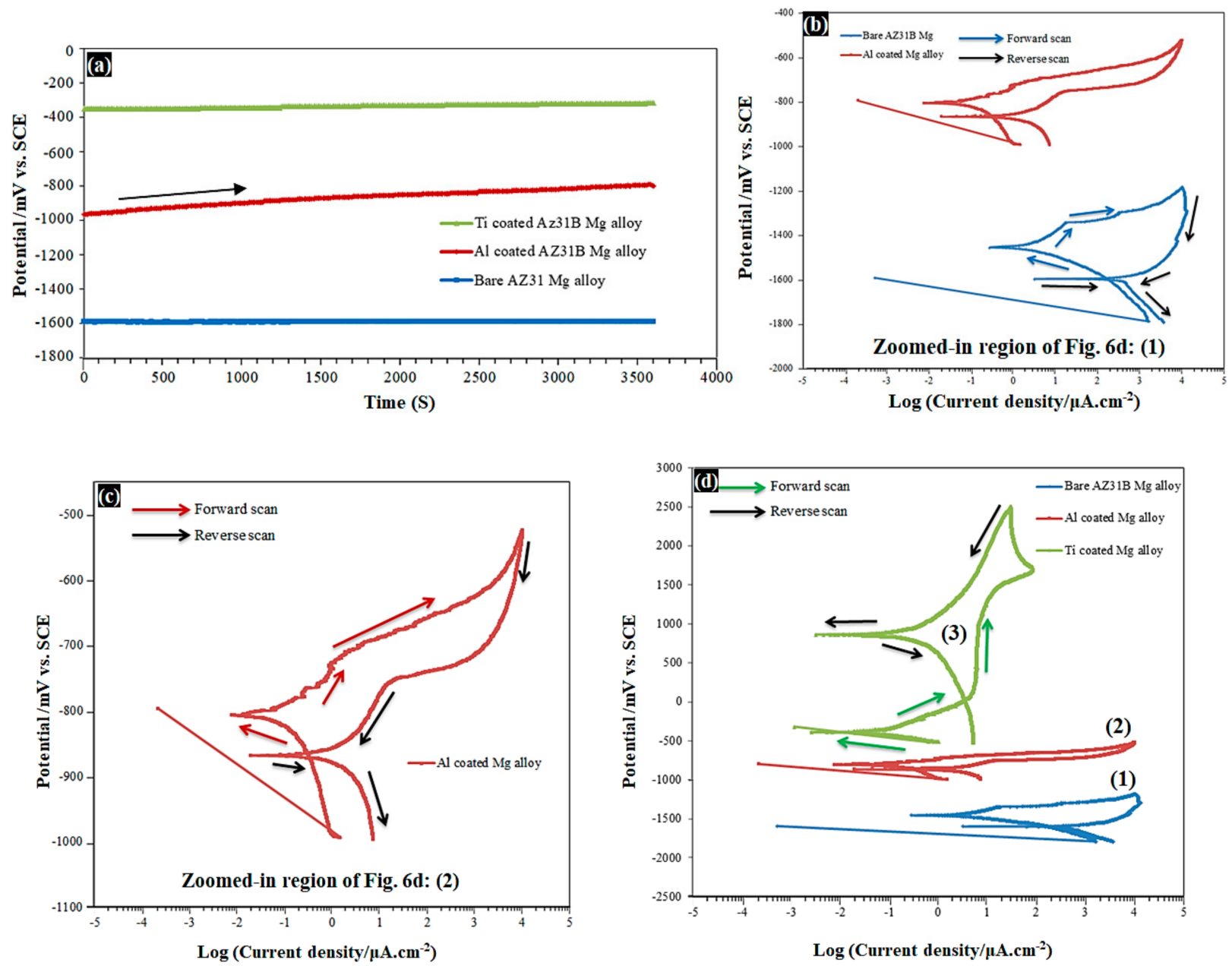

Figure 6. (a) Open circuit potential (OCP) for $1 \mathrm{~h}$, and (b-d) cyclic potentiodynamic polarization (CPP) curves for bare and coated AZ31B Mg alloys in $3.5 \mathrm{wt} \% \mathrm{NaCl}$ electrolyte.

Cyclic potentiodynamic polarization tests (Figure $6 \mathrm{~b}-\mathrm{d}$ ) were carried out to determine whether coated and uncoated AZ31B alloys experience pitting corrosion in chloride containing solutions. This test can also help whether the passive film formed on the surface 
has a tendency to heal itself (or repassivate) in the harsh environment. Moreover, CPP test was carried out three times to prove the repeatability of the obtained outcomes.

The corrosion parameters for the bare AZ31B samples as well as Al-and Ti-coated samples are given in Table 3. It is clear that Al-and Ti-coated AZ31B alloy samples have lower corrosion current densities $\left(i_{\text {corr }}\right)$ compared to bare samples, where lowest $i_{\text {corr }}$ and average corrosion rate $\left(P_{\mathrm{i}}=22.85 i_{\text {corr }}\right.$ [43]) were observed for Ti-coated samples. The corrosion potential values were more noble for Al-coated and further higher for Ticoated samples. Overall, it could be suggested that both $\mathrm{Al}$ and Ti cold sprayed coating improved the corrosion behavior of AZ31B alloy, obviously much better in case of Ti-coated samples. In this research, HPCS Ti coating considerably lowered $i_{\text {corr }}$ to $0.049 \mu \mathrm{A} / \mathrm{cm}^{2}$ from $2.504 \mu \mathrm{A} / \mathrm{cm}^{2}$ and shifted $E_{\mathrm{corr}}$ to more noble potential, i.e., $-387.299 \mathrm{mV}_{\mathrm{SCE}}$ from $-1453.86 \mathrm{mV}_{\mathrm{SCE}}$ for AZ31B Mg alloy in $3.5 \mathrm{wt} \% \mathrm{NaCl}$ solution. Nonetheless, magnetron sputtered Ti coating could only lower $i_{\text {corr }}$ to $26.60 \mu \mathrm{A} / \mathrm{cm}^{2}$ from $162.70 \mu \mathrm{A} / \mathrm{cm}^{2}$ and $E_{\text {corr }}$ to $-1525 \mathrm{mV}_{\mathrm{SCE}}$ from $-1570 \mathrm{mV}_{\mathrm{SCE}}$ for $\mathrm{AZ91D} \mathrm{Mg}$ alloy in $3.5 \mathrm{wt} \% \mathrm{NaCl}$ solution [32].

Table 3. The $E_{\text {corr }}$ and $i_{\text {corr }}, \beta_{\mathrm{a}}$ and $\beta_{\mathrm{c}}$ for bare and coated samples calculated from the forward scan of cyclic potentiodynamic polarization (CPP) curves.

\begin{tabular}{ccccc}
\hline Type of Sample & $\boldsymbol{E}_{\text {corr }}\left(\mathbf{m} \mathbf{V}_{\text {SCE }}\right)$ & $\beta_{\mathbf{a}}(\mathbf{m V} / \mathbf{d e c})$ & $\beta_{\mathbf{c}}(\mathbf{m V} / \mathbf{d e c})$ & $i_{\text {corr }}\left(\boldsymbol{\mu} \mathbf{A} \mathbf{~ c m}^{-2}\right)$ \\
\hline AZ31B & -1453.86 & 115.3 & 67.6 & 2.504 \\
Al-coated AZ31B & -804.59 & 75.5 & 114 & 0.092 \\
Ti-coated AZ31B & -387.299 & 159.9 & 99.7 & 0.049 \\
\hline
\end{tabular}

The difference between pitting potential $E_{\text {pit }}$ and $E_{\text {corr }}\left(E_{\text {pit }}-E_{\text {corr }}\right)$ can be used as a measure of the propensity to the pitting nucleation [22]. Moreover, the difference between repassivation or protection potential $\left(E_{\mathrm{rp}}\right)$ and corrosion potential $E_{\mathrm{corr}}\left(E_{\mathrm{rp}}-E_{\mathrm{corr}}\right)$ can be employed as a measure of the repassivation ability. Lager values of $\left(E_{\mathrm{pit}}-E_{\mathrm{corr}}\right)$ and $\left(E_{\mathrm{rp}}-E_{\mathrm{corr}}\right)$ signify enhanced resistance to pitting corrosion and higher repassivation ability, respectively [22]. The $E_{\mathrm{rp}}-E_{\text {corr }}$ values increase in the order: $\mathrm{AZ31B}<\mathrm{Al}$-coated AZ31B $<<$ Ti-coated AZ31B. On the reverse scan, AZ31B and Al-coated AZ31B showed a positive hysteresis loop, implying the further growth of pitting. It was reported that pitting corrosion can't get further expanded if reversed anodic curve shifted to lower current densities (as negative hysteresis loops) or the forward scan to be retraced by reversed curve. On the contrary, further pitting development is anticipated if reversed anodic curve shifted to higher current densities compared to forward scan (as positive hysteresis loops) [44]. The pits keep growing if $E_{\mathrm{corr}}>E_{\mathrm{rp}}$ and vice versa. Ti-coated $\mathrm{Mg}$ alloy indicates negative hysteresis loop, depicting repassivation of pits, in contrast to AZ31B and Al-coated AZ31B with positive hysteresis loops where $E_{\mathrm{corr}}>E_{\mathrm{rp}}$; indicating irreversible growth of pits. As-cold sprayed $\mathrm{Nb}$ coatings (from group 5B) also showed negative hysteresis loops. The repassivation behavior of CS Nb coating was attributed to the stored energy in the CS coatings assisting to passivate quickly and simply [45]. Analysis of $E_{\mathrm{pit}}-E_{\mathrm{corr}}$ values demonstrates that $\mathrm{AZ} 31 \mathrm{~B}$ and $\mathrm{Al}$-coated AZ31B are most susceptible to pitting corrosion while Ti-coated $\mathrm{Mg}$ alloy indicates conspicuous resistance to pitting in chloride containing electrolyte.

The CPP tests also reveal that the anodic curves for AZ31B and Al-coated AZ31B had active current densities especially in case of AZ31B alloy. The cathodic current kinetics were highest for AZ31B compared to both Al-coated and Ti-coated alloys samples. The current density limit of $10 \mathrm{~mA} / \mathrm{cm}^{2}$ was reached at much lower potentials for AZ31B and Al-coated AZ31B alloy as well. Among all Ti-coated samples showed primary passivation followed by a secondary passivation (passive-like behavior) through a passive-activepassive (passive-like behavior) transition region. Interestingly, after the reaching the upper potential limit of $2.5 \mathrm{~V}_{\mathrm{SCE}}$ the reverse scan showed lower current densities suggesting that the surface is still passive and lower potential cause lower dissolution for the passivated Ti surface. This is a very good indication of highly stable passive film which did not deteriorate even at such potentials. 


\subsubsection{Electrochemical Impedance Spectroscopy (EIS)}

For further elucidation of the influence of cold sprayed coatings on the corrosion behavior of AZ31B Mg alloy, electrochemical impedance spectroscopy (EIS) of coated and uncoated Mg alloys was measured at their OCP. Nyquist plots are shown in Figure 7a,b. The impedance spectra was fitted by the electrical equivalent circuits (shown in Figure 7c,d: models 1 and 2). For the Nyquist diagram of uncoated sample (Figure 7d), one inductive loop and one capacitive loop at low frequency and high frequency were considered, respectively. This assumption is in harmony with the previous researches $[26,46]$. EEC (electrical equivalent circuit) for uncoated $\mathrm{Mg}$ alloy is comprised of $R_{\mathrm{ct}}$ (charge transfer resistance), $R_{\mathrm{s}}$ (electrolyte resistance), $C_{\mathrm{dl}}$ (CPE related to electrical double layer), adsorption inductance $(L)$ and adsorption resistance $\left(R_{\mathrm{L}}\right)$ elements.
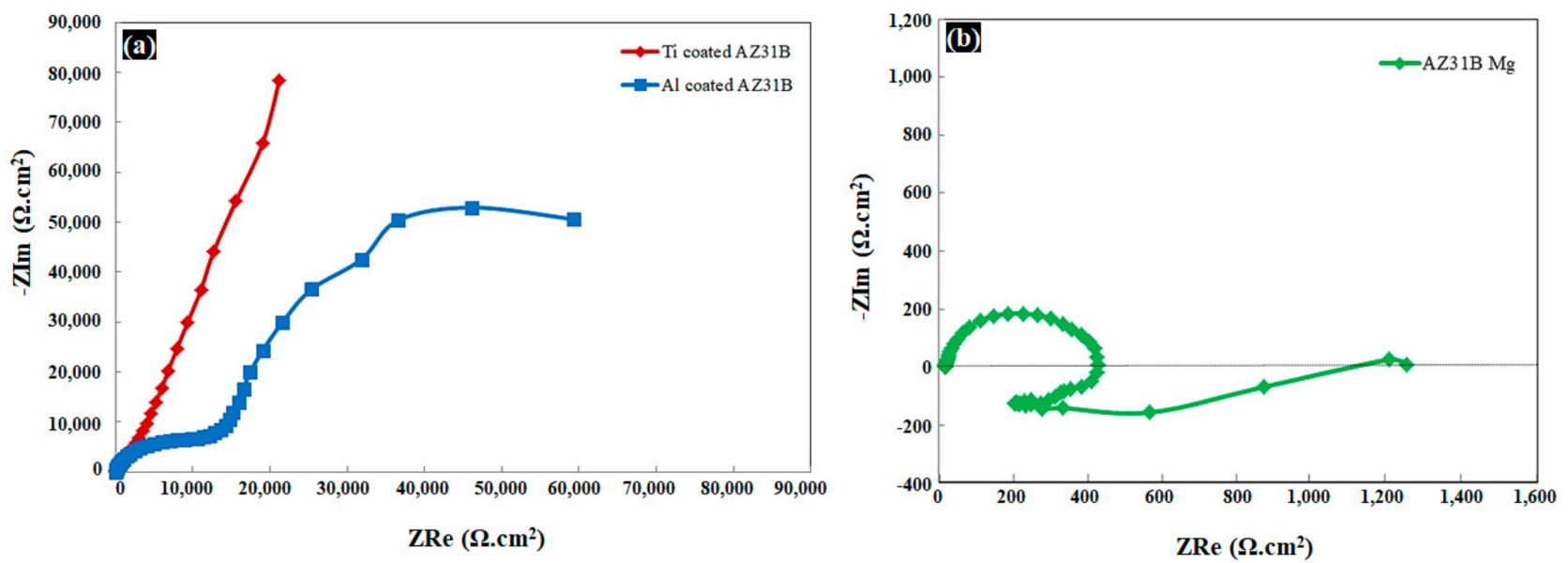

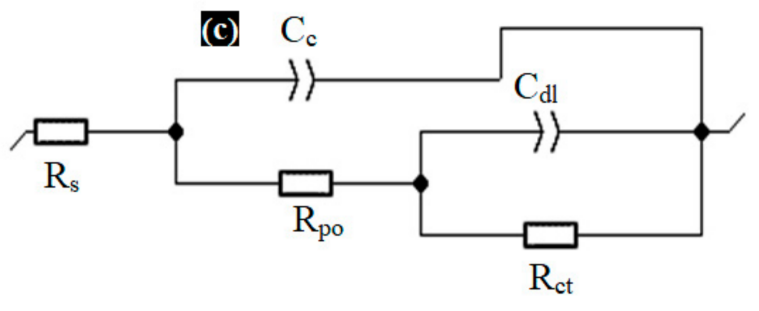

Used for coated AZ31B: Model 1

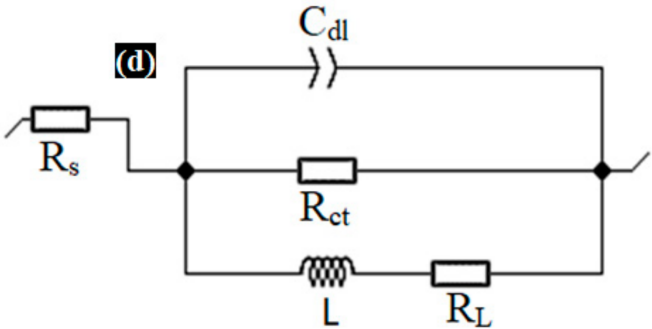

Used for uncoated AZ31B: Model 2

Figure 7. Nyquist plots of $(\mathbf{a}, \mathbf{b})$ coated and uncoated AZ31B Mg alloy substrates at OCP, electrical equivalent circuits to fit the impedance spectra of (c) coated AZ31B Mg alloys (model 1), and (d) bare AZ31B Mg alloys (model 2).

Impedance spectra of the coated samples were fitted by using the electrical equivalent circuit, as shown schematically in Figure 8. This schematically EEC includes $R_{\mathrm{S}}$ which is ohmic solution resistance at the working electrode/reference electrode interface; loop $R_{\mathrm{ox}}-C_{\mathrm{ox}}$ which shows the resistance $\left(R_{\mathrm{c}}\right.$ or $\left.R_{\mathrm{ox}}\right)$ and capacitance $\left(C_{\mathrm{c}}\right.$ or $\left.C_{\mathrm{ox}}\right)$ of the oxide film; $R_{\mathrm{ct}}$ and $C_{\mathrm{dl}} ; R_{\mathrm{po}}$ that is the electrolyte resistance (as additional resistance) in the localized corrosion sites (and/or the pores). The $R_{\mathrm{c}}$ or $R_{\mathrm{ox}}$ values are pretty high and any conduction of electrons through the oxide layer has been reported to be impossible $[47,48]$. Thus, Mansfeld and Kendig [49] proposed the removal of this circuit element from EEC and replacement of EEC1 with EEC2 $[47,48]$. This simplified EEC2 has been also reported in the previous researches [49-52], so a capacitive loop at high frequency and another capacitive loop at low frequency regions were assumed for the coated $\mathrm{Mg}$ samples. Likewise, with regard to the non-ideality of the systems, the capacitors were replaced with the constant phase elements (CPE) for all samples $[51,53]$. 


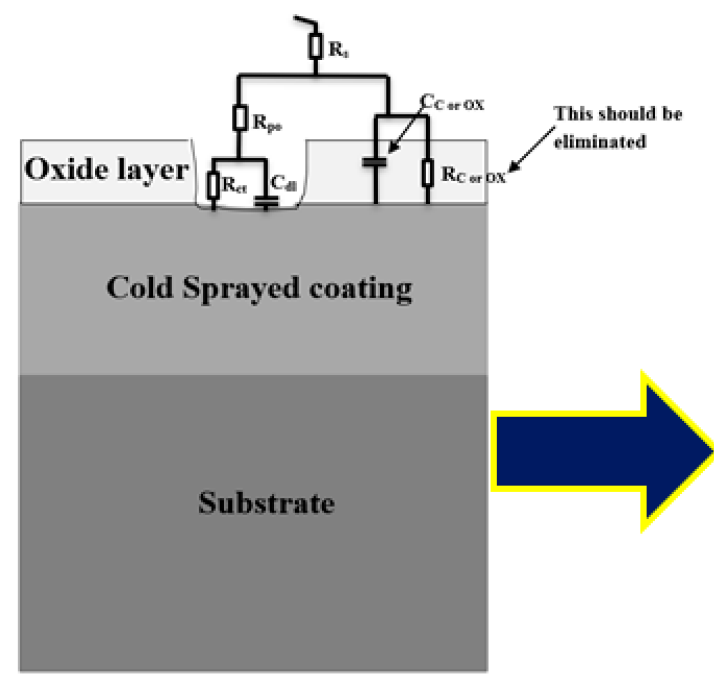

EEC1

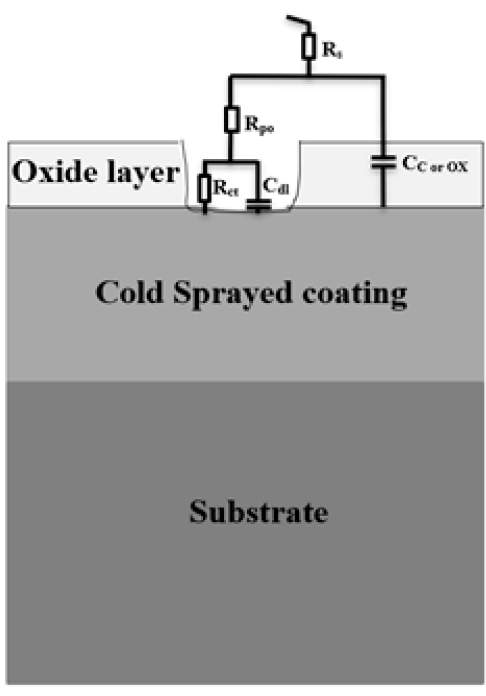

EEC2

Figure 8. Schematic illustration of the developed EEC for fitting impedance spectra of CS Ti and CS Al-coated samples (per previous studies).

$R_{\text {ct }}$ can predominantly control the electrochemical processes rate at the interface between electrode and electrolyte (or across the electrical double layer) [54,55]. As a matter of fact, corrosion rate is reversely proportional to the $R_{\mathrm{ct}}[56,57]$. As presented in Table 4 , Bare AZ31B Mg alloy with the lowest $R_{\mathrm{ct}}$ showed the maximum corrosion rate between 3 samples. This could be attributed to the low protective performance of the formed corrosion surface film on the $\mathrm{Mg}$ alloy surface in corrosive solution. Nevertheless, values of $R_{\mathrm{ct}}$ for Al- and Ti-coated samples were $164.707 \mathrm{k} \Omega \cdot \mathrm{cm}^{2}$, and $5580 \mathrm{k} \Omega \cdot \mathrm{cm}^{2}$, respectively. This indicates that $\mathrm{Mg}$ alloy could be protected by $\mathrm{Al}$ and Ti coatings. Nevertheless, $R_{\mathrm{ct}}$ value for the Ti-coated $\mathrm{Mg}$ alloy is roughly 34 times the value of $R_{\mathrm{ct}}$ for the Al-coated $\mathrm{Mg}$ alloy. The above-mentioned results reveal that the CS titanium coating can substantially declines the corrosion rate $\left(1 / R_{\mathrm{ct}}\right)$ of $\mathrm{Mg}$ alloy in chloride containing solutions.

Table 4. EIS fitted results for bare and coated samples in $3.5 \mathrm{wt} \% \mathrm{NaCl}$ electrolyte.

\begin{tabular}{|c|c|c|c|c|c|c|c|c|c|}
\hline Samples & $\begin{array}{c}R_{\mathrm{S}} \\
\left(\Omega \mathrm{cm}^{2}\right)\end{array}$ & $\begin{array}{c}R_{\mathrm{ct}} \\
\left(\Omega \mathrm{cm}^{2}\right)\end{array}$ & $\begin{array}{c}Q_{\mathrm{dl}} \\
\left(\mathrm{F} \mathrm{cm}^{-2} \mathrm{~s}^{n-1}\right)\end{array}$ & $n$ & $\begin{array}{c}R_{\text {po }} \\
\left(\Omega \mathrm{cm}^{2}\right)\end{array}$ & $\begin{array}{c}Q_{\mathrm{c}} \\
\left(\mathrm{F} \mathrm{cm}^{-2} \mathrm{~s}^{n-1}\right)\end{array}$ & $n$ & $\begin{array}{c}R_{\mathrm{L}} \\
\left(\Omega \mathrm{cm}^{2}\right)\end{array}$ & $\begin{array}{c}L \\
\left(\mathrm{H} \mathrm{cm}^{2}\right)\end{array}$ \\
\hline $\begin{array}{c}\text { Bare } \\
\text { AZ31B } \\
\text { Mg alloy }\end{array}$ & 18.31 & 385.6 & $1.13 \times 10^{-5}$ & 0.98 & - & - & - & 187.9 & 187.5 \\
\hline $\begin{array}{l}\text { Al-coated } \\
\text { Mg alloy }\end{array}$ & 15.18 & 164707 & $0.116 \times 10^{-3}$ & 0.87 & 14397 & $9.68 \times 10^{-6}$ & 0.88 & - & - \\
\hline $\begin{array}{l}\text { Ti-coated } \\
\text { Mg alloy }\end{array}$ & 17.69 & $5.58 \times 10^{6}$ & $66.67 \times 10^{-6}$ & 0.798 & 6059 & $59.33 \times 10^{-6}$ & 0.90 & - & - \\
\hline
\end{tabular}

It is worth mentioning that the corrosion resistance could be characterized by the parameter of polarization resistance at the corrosion potential $\left(R_{\text {pol }}\right)$. Values of $R_{\text {pol }}$ for $\mathrm{Al}$ and Ti-coated samples were calculated using Equation (2) under EEC2 (Model 1) in Figure 7c [58-63].

$$
R_{\mathrm{pol}}=R_{\mathrm{po}}+R_{\mathrm{ct}}
$$

AZ31B coated with Ti coating showed the much better corrosion resistance than Al-coated $\mathrm{Mg}$ alloy in $3.5 \mathrm{wt} \% \mathrm{NaCl}$ solution. It is expected that this unprecedented development could be maintained even during longer immersion times. 


\subsection{Long Term Immersion Test in 3.5 wt \% NaCl Solution for 11 Days}

The surface morphological characteristics of ground coated and uncoated AZ31BMg alloys after immersion test (in $3.5 \mathrm{wt} \% \mathrm{NaCl}$ solution for $264 \mathrm{~h}$ ) are shown in Figures 9-12. Uneven corrosion products with some micro-cracks [64] (Figure 9a,b,f) entirely covered the surface of the bare AZ31B Mg alloy surface. Corrosion products on the corroded bare $\mathrm{AZ31B} \mathrm{Mg}$ alloy surface were mostly comprised of $\mathrm{Mg}, \mathrm{O}, \mathrm{Cl}$ as well as $\mathrm{Al}$, and $\mathrm{Na}$ elements (Figure $9 \mathrm{c}-\mathrm{e}$ ). The presence of $\mathrm{Mg}, \mathrm{O}$ and $\mathrm{Cl}$ elements (Figure $9 \mathrm{~d}, \mathrm{e}$ ) in the corrosion products was related to the possible existence of $\mathrm{MgCl}_{2}$ and $\mathrm{Mg}(\mathrm{OH})_{2}$ phases [57]. Nonetheless, the lower corrosion current density, higher $R_{\mathrm{ct}}$, and $E_{\mathrm{corr}}$ were all obtained for the AZ31BMg alloy when $\mathrm{Al}$ coating was applied on the AZ31B alloy (during short term electrochemical corrosion tests). Moreover, no significant corrosion was observed for the Al-coated AZ31B at the beginning of immersion test. However, deeper and even broad corrosion pits and also local net-cracks of corrosion products imply that the localized corrosion is worsened after $264 \mathrm{~h}$ of immersion (Figure 10a,b,f). In fact, the pitting density rises with uniform corrosion in the course of immersion time in chloride containing solutions. This behavior is also reported for the morphology of $\mathrm{Al}$ after corrosion $[65,66]$.

Corrosion products on the corroded $\mathrm{Al}$ coating surface after $264 \mathrm{~h}$ of immersion were mainly constituted by $\mathrm{Al}, \mathrm{Mg}$ and $\mathrm{O}$ as well as $\mathrm{Cl}$ and $\mathrm{Na}$ elements (Figure 10c-e). $\mathrm{Mg}$ element (from the AZ31B Mg substrate) was detected on the corroded Al coating surface. $\mathrm{Al}$ coating with low compactness could conduct chloride containing solution into the interior regions of the coating over immersion time. In fact, Al coating can't separate the AZ31B alloy surface from the corrosive electrolyte during long term immersion for 11 days.

High pressure cold sprayed $\mathrm{Ti}$ (from group 4B) coating (with high propensity to repassivation and also high pitting corrosion resistance) considerably mitigated the drawbacks associated with CP-Al coating (in this research). The corroded Ti coating surface didn't show any conspicuous corrosion pits and the other localized corrosions after long term immersion (Figure 11). It is interesting to note that, scratches (grinding tracks due to the coating surface preparation before the corrosion tests) are still distinguishable (Figure 11a,b,g) on the Ti coating surface even after 11 days of immersion.

Figure $11 \mathrm{c}-\mathrm{f}$ show that corrosion products are primarily constituted by $\mathrm{Ti}$ and $\mathrm{O}$ elements which might correspond to existence of titanium-oxides [28] on the corroded coating surface. Likewise, Mg element (from AZ31B alloy substrate) wasn't detected on the corroded Ti layer surface. In fact, the Ti layer can considerably separate the AZ31BMg alloy surface from the corrosive electrolyte even during long-term immersion for 11 days.

On the contrary, galvanic cell formation between $\mathrm{Mg}$ alloy substrate and warm sprayed Ti coatings were observed by Moronczyk et.al [31]. This led to the corrosion products formation and their pile up at the interface between WS Ti coating and Mg alloy substrate. This finally caused the sudden rupture of the WS Ti coatings after merely $24 \mathrm{~h}$ of immersion test in $3.5 \mathrm{wt} \% \mathrm{NaCl}$ electrolyte [31]. This behavior was also seen for magnetron sputtered Ti coating on AZ91D after $24 \mathrm{~h}$ of immersion in chloride coating solution [32]. This indicates that HPCS titanium coating not only modifies the hardness and wear behavior of Mg alloys, but also can exceptionally enhance the corrosion resistance of $\mathrm{Mg}$ alloys in aggressive solutions during long run immersion in chloride containing solution. 

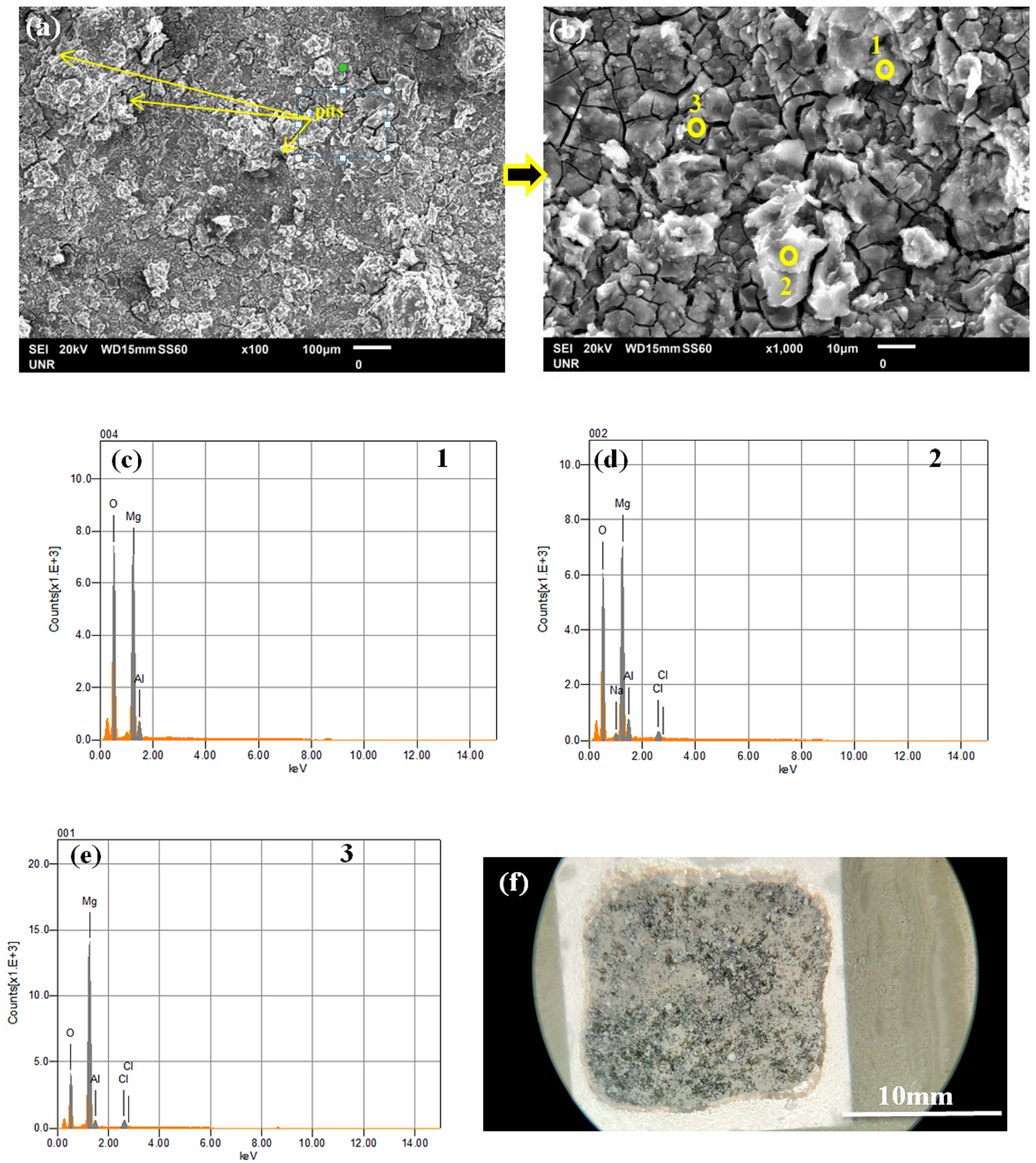

Figure 9. (a,b) surface morphology of ground surface of uncoated AZ31B Mg alloy after immersion test in $3.5 \mathrm{wt} \% \mathrm{NaCl}$ solution for 11 days, EDS analysis of 1 (c), 2 (d), 3 (e) and (f) stereo microscope image at $50 \times$ magnification. 

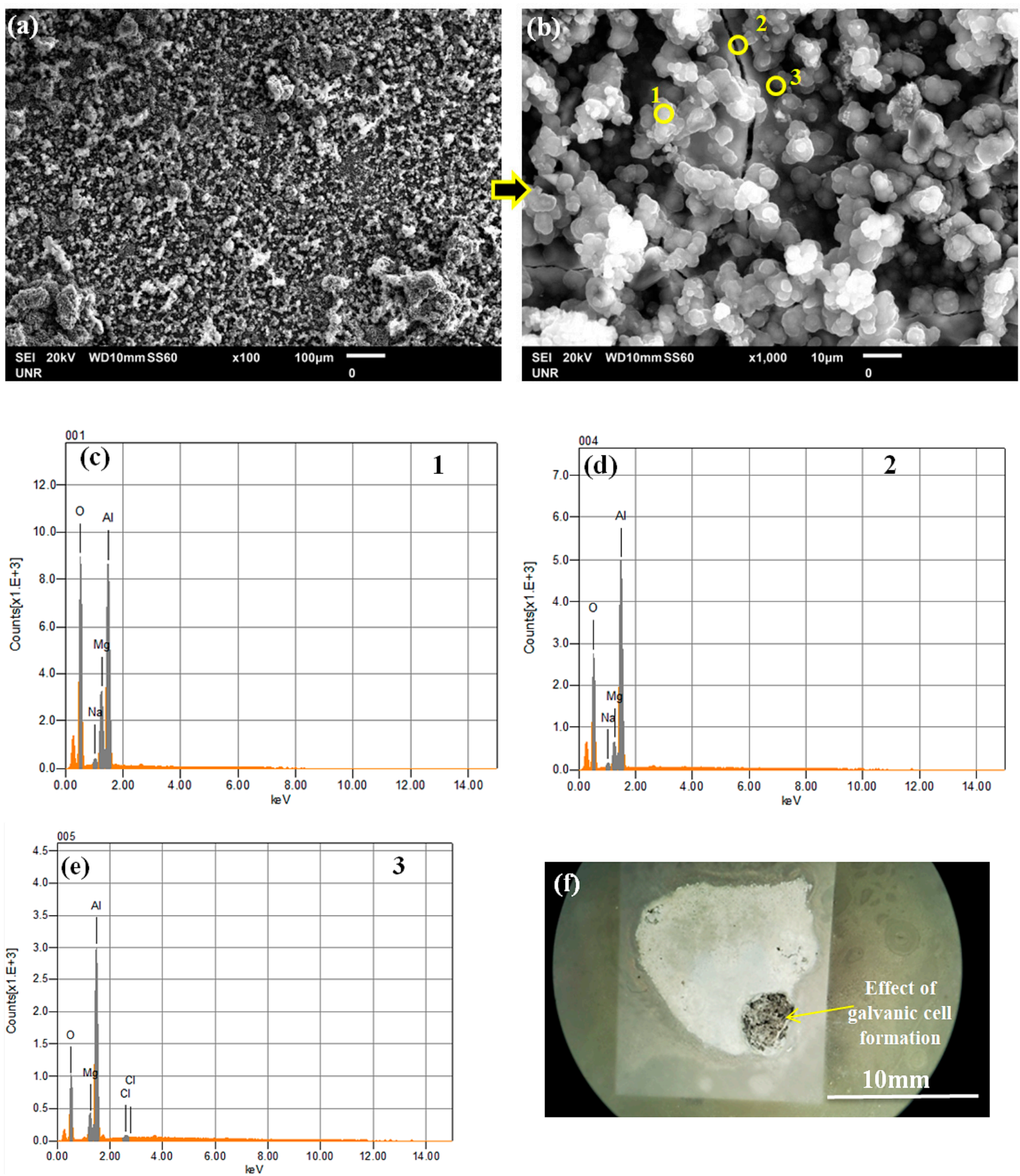

Figure 10. (a,b) surface morphology of ground surface of Al-coated AZ31B after immersion test in $3.5 \mathrm{wt} \% \mathrm{NaCl}$ solution for 11 days, EDS analysis of 1 (c), 2 (d), 3 (e) and (f) stereo microscope image at $50 \times$ magnification. 

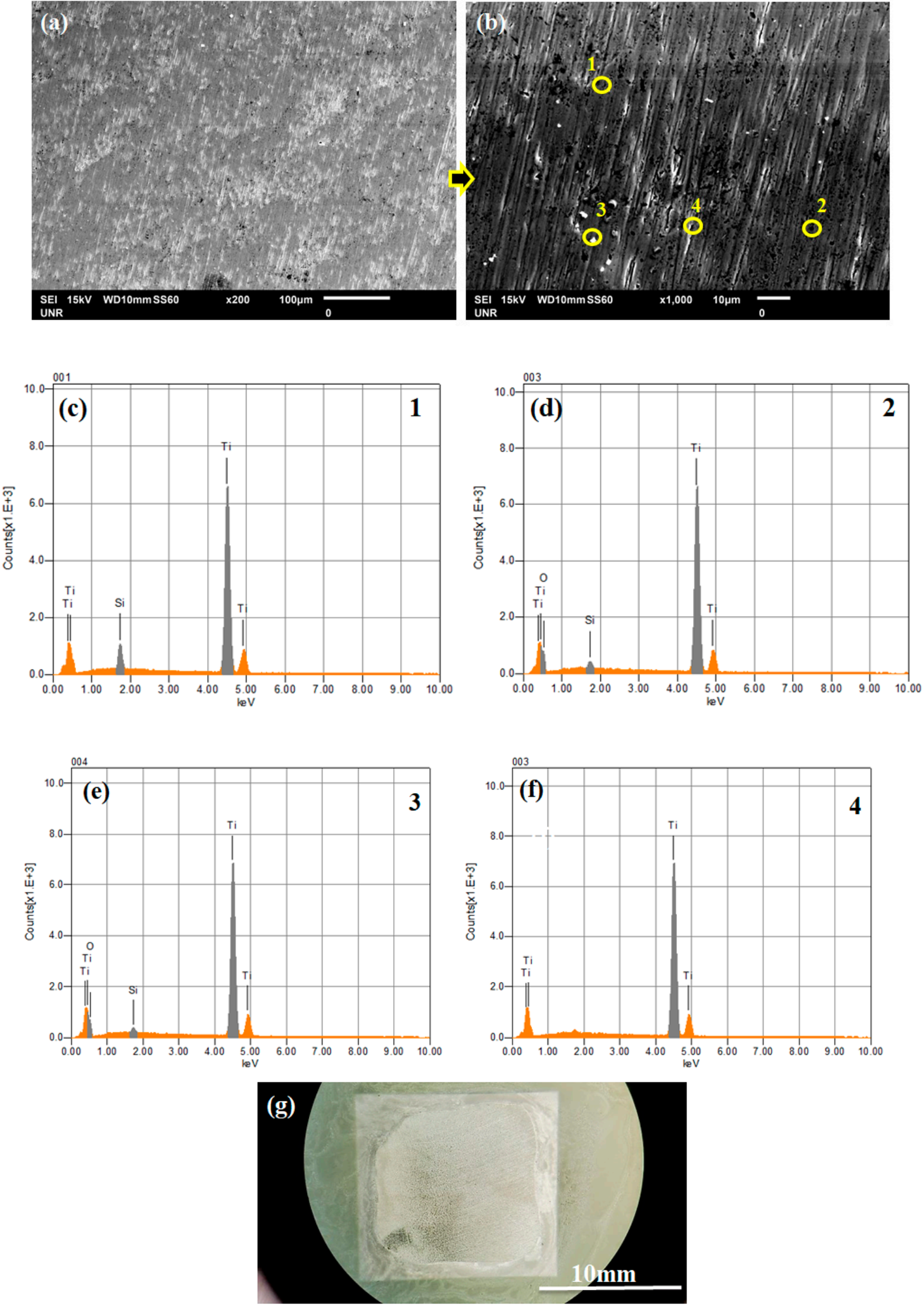

Figure 11. (a,b) surface morphology of ground surface of Ti-coated AZ31B after immersion test in $3.5 \mathrm{wt} \% \mathrm{NaCl}$ solution for 11 days, EDS analysis of 1 (c), 2 (d), 3 (e), 4 (f) and (g) stereo microscope image at $50 \times$ magnification. 


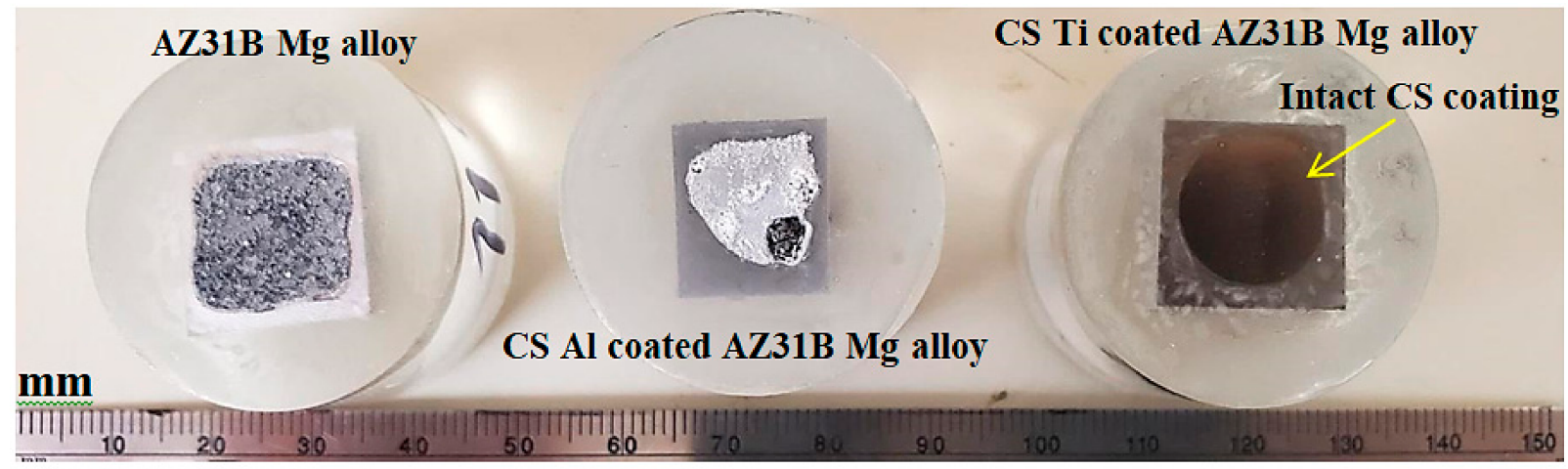

After 11 days of immersion

Figure 12. Photos of uncoated AZ31B Mg alloy, Al-coated AZ31B Mg alloy, and Ti-coated AZ31B Mg alloy (from left to right) after immersion test in $3.5 \mathrm{wt} \% \mathrm{NaCl}$ solution for 11 days.

\section{Conclusions}

CS Ti coatings improved the hardness and wear behavior of Mg alloys compared to CS Al coatings. AZ31B coated with Ti coating showed the much better corrosion resistance than Al-coated $\mathrm{Mg}$ alloy in $3.5 \mathrm{wt} \% \mathrm{NaCl}$ solution. AZ31B and Al-coated AZ31B were most vulnerable to pitting corrosion, while Ti-coated $\mathrm{Mg}$ alloy indicated extraordinary resistance to pitting in chloride containing electrolyte. Compared to CS Al coating, cold sprayed commercially pure-Ti coating exceptionally increased the repassivation ability of Mg alloys. Moreover, immersion test for 11 days further elucidated the effectiveness and corrosion protection performance of HPCS Ti coatings on Mg alloys in corrosive solutions.

Author Contributions: Conceptualization, M.D.; methodology, A.K.K., M.U.F.K. and C.M.K.; validation, A.K.K., M.U.F.K., P.L.M. and R.K.G.; formal analysis, M.D., A.K.K., M.U.F.K., P.L.M. and R.K.G.; investigation, M.D. and M.U.F.K.; resources, P.L.M., C.M.K., M.M. and R.K.G.; data curation, A.K.K., M.U.F.K., P.L.M. and R.K.G.; writing—original draft preparation, M.D., A.K.K. and M.U.F.K.; writing-review and editing, M.D., A.K.K., M.U.F.K., P.L.M., C.M.K., M.M. and R.K.G.; visualization, P.L.M.; supervision, M.D., P.L.M. and R.K.G.; project administration, M.D., C.M.K. and M.M.; funding acquisition, C.M.K., M.M. and R.K.G. All authors have read and agreed to the published version of the manuscript.

Funding: This research was funded by National Science Foundation, grant number NSF-CMMI 1846887.

Institutional Review Board Statement: Not applicable.

Informed Consent Statement: Not applicable.

Data Availability Statement: Data sharing not applicable.

Acknowledgments: The authors would like to acknowledge the ASB Industries, Inc for providing facilities and support. R. K. Gupta acknowledges the financial support from the National Science Foundation (NSF-CMMI 1846887) under the direction of Alexis Lewis. M. Misra duly acknowledges the startup fund from the University of Nevada: Reno.

Conflicts of Interest: The authors declare no conflict of interest.

\section{References}

1. Yi, A.; Du, J.; Wang, J.; Mu, S.; Zhang, G.; Li, W. Preparation and characterization of colored Ti/Zr conversion coating on AZ91D magnesium alloy. Surf. Coat. Technol. 2015, 276, 239-247. [CrossRef]

2. Daroonparvar, M.; Yajid, M.A.M.; Yusof, N.M.; Bakhsheshi-Rad, H.R.; Hamzah, E.; Kamali, H.A. Microstructural characterization and corrosion resistance evaluation of nanostructured $\mathrm{Al}$ and $\mathrm{Al} / \mathrm{AlCr}$ coated $\mathrm{Mg}-\mathrm{Zn}-\mathrm{Ce}-\mathrm{La}$ alloy. Alloys Compd. 2014, 615, 657-671. [CrossRef]

3. Singh, C.; Tiwari, S.K.; Singh, R. Exploring environment friendly nickel electrodeposition on AZ91 magnesium alloy: Effect of prior surface treatments and temperature of the bath on corrosion behavior. Corros. Sci. 2019, 151, 1-19. [CrossRef] 
4. Daroonparvar, M.; Yajid, M.M.A.; Yusof, M.N.; Bakhsheshi-Rad, R.H. Fabrication and properties of triplex $\mathrm{NiCrAlY} / \mathrm{nano} \mathrm{Al}_{2} \mathrm{O}_{3}$. $13 \% \mathrm{TiO}_{2} /$ nano $\mathrm{TiO}_{2}$ coatings on a magnesium alloy by atmospheric plasma spraying method. Alloys Compd. 2015, 645, 450-466. [CrossRef]

5. Carboneras, M.; López, M.D.; Rodrigo, P.; Campo, M.; Torres, B.; Otero, E.; Rams, J. Corrosion behaviour of thermally sprayed Al and $\mathrm{Al} / \mathrm{SiCp}$ composite coatings on ZE41 magnesium alloy in chloride medium. Corros. Sci. 2010, 52, 761-768. [CrossRef]

6. Daroonparvar, M.; Yajid, M.M.; Bakhsheshi-Rad, R.H.; Yusof, M.N.; Izman, S.; Hamzah, E.; Kadir, A.M. Corrosion resistance investigation of nanostructured $\mathrm{Si}$-and $\mathrm{Si}$ / TiO2-coated $\mathrm{Mg}$ alloy in 3.5\% NaCl solution. Vacuum 2014, 108, 61-65.

7. Bakhsheshi-Rad, R.H.; Hamzah, E.; Ebrahimi-Kahrizsangi, R.; Daroonparvar, M.; Medraj, M. Fabrication and characterization of hydrophobic micro arc oxidation/poly-lactic acid duplex coating on biodegradable Mg-Ca alloy for corrosion protection. Vacuum 2016, 125, 185-188. [CrossRef]

8. Daroonparvar, M.; Yajid, M.M.; Bakhsheshi-Rad, H.R.; Ku-mar, P.; Kay, C.M.; Kalvala, P.R. Fabrication and Corrosion Resistance Evaluation of Novel Epoxy/Oxide Layer (MgO) Coating on Mg Alloy. Prot. Met. Phys. Chem. Surf. 2020, 56, 1039-1050. [CrossRef]

9. Daroonparvar, M.; Yajid, M.M.; Yusof, N.M.; Bakhsheshi-Rad, H.R.; Adabi, M.; Hamzah, E.; Kamali, H.A. Improvement of corrosion resistance of binary Mg-Ca alloys using duplex alu-minum-chromium coatings. J. Mater. Eng. Perform. 2015, 7, 2614-2627. [CrossRef]

10. Daroonparvar, M.; Yajid, M.M.; Gupta, R.K.; Yusof, N.M.; Bakhsheshi-Rad, H.R.; Ghandvar, H. Investigation of Corrosion Protection Performance of Multiphase PEO $\left(\mathrm{Mg}_{2} \mathrm{SiO}_{4}, \mathrm{MgO}, \mathrm{MgAl}_{2} \mathrm{O}_{4}\right)$ Coatings on $\mathrm{Mg}$ Alloy Formed in Aluminate-Silicatebased Mixture Electrolyte. Prot. Met. Phys. Chem. Surf. 2018, 54, 425-441. [CrossRef]

11. Widener, A.C.; Ellingsen, M.; Carter, M. Understanding Cold Spray for Enhanced Manufacturing Sustainability. Mater. Sci. Forum 2018, 941, 1867-1873. [CrossRef]

12. Monette, Z.; Kasar, K.A.; Daroonparvar, M.; Menezes, L.P. Supersonic particle deposition as an additive technology: Methods, challenges, and applications. Int. J. Adv. Manuf. Technol. 2020, 106, 2079-2099. [CrossRef]

13. Kay, C.M.; Karthikeyan, J. High Pressure Cold Spray: Principles and Applications; ASM Thermal Spray Society: Materials Park, OH, USA, 2016; ISBN 978-1-62708-096-5.

14. Zulkifli, I.S.M.; Yajid, M.A.M.; Idris, M.H.; Uday, M.B.; Daroonparvar, M.; Emadzadeh, A.; Arshad, A. Micro-structural evaluation and thermal oxidation behaviors of YSZ/NiCoCrAlYTa coatings deposited by different thermal techniques. Ceram. Int. 2020, 46, 22438-22451. [CrossRef]

15. Daroonparvar, M.; Yajid, M.A.M.; Kay, C.M.M.; Bakhsheshi-Rad, H.; Gupta, R.K.; Yusof, N.M.; Ghandvar, H.; Arshad, A.; Zulkifli, I.S.M. Effects of $\mathrm{Al}_{2} \mathrm{O}_{3}$ diffusion barrier layer (including Y-containing small oxide precipitates) and nanostructured YSZ top coat on the oxidation behavior of HVOF NiCoCrAl-TaY/APS YSZ coatings at $1100^{\circ} \mathrm{C}$. Corros. Sci. 2018, 144, 13-34. [CrossRef]

16. Luo, X.T.; Li, C.X.; Shang, F.L.; Yang, G.J.; Wang, Y.Y.; Li, C.J. High velocity impact induced microstructure evolution during deposition of cold spray coatings. Surf. Coat. Technol. 2014, 254, 11-20. [CrossRef]

17. Assadi, H.; Kreye, H.; Gärtner, F.; Klassen, T. Cold spraying: A materials perspective. Acta Mater. 2016, 116, 382-407. [CrossRef]

18. Daroonparvar, M.; Yajid, M.A.M.; Yusof, N.M.; Bakhsheshi-Rad, H.R.; Hamzah, E. Microstructural characterisation of air plasma sprayed nanostructure ceramic coatings on Mg-1\% Ca alloys (bonded by NiCoCrAlYTa). Ceram. Int. 2016, 42, 357-371. [CrossRef]

19. Daroonparvar, M.; Yajid, M.M.; Yusof, N.M.; Bakhsheshi-Rad, H.R.; Hussain, M.; Hamzah, E. Evaluation of Normal and Nanolayer Composite Thermal Barrier Coatings in Fused Vanadate-Sulfate Salts at $1000{ }^{\circ}$ C. Adv. Mater. Sci. Eng. 2013, 2013, 1-13. [CrossRef]

20. Bakhsheshi-Rad, H.R.; Abdellahi, M.; Hamzah, E.; Daroonparvar, M.; Rafiei, M. Introducing a composite coating containing CNTs with good corrosion properties: Characterization and simulation. RSC Adv. 2016, 6, 108498-108512. [CrossRef]

21. Wang, J.; Pang, X.; Jahed, H. Surface protection of Mg alloys in automotive applications: A review. Mater. Sci. 2019, 6, 567-600 [CrossRef]

22. Tao, Y.; Xiong, T.; Sun, C.; Kong, L.; Cui, X.; Li, T.; Song, G.L. Microstructure and corrosion performance of a cold sprayed aluminium coating on AZ91D magnesium alloy. Corros. Sci. 2010, 52, 3191-3197. [CrossRef]

23. DeForce, B.S.; Eden, T.J.; Potter, J.K. Cold spray Al-5\% Mg coatings for the corrosion protection of magnesium alloys. J. Therm. Spray Technol. 2011, 20, 1352-1358. [CrossRef]

24. Diab, M.; Pang, X.; Jahed, H. The effect of pure aluminum cold spray coating on corrosion and corrosion fatigue of magnesium (3\% Al-1\% Zn) extrusion. Surf. Coat. Technol. 2017, 309, 423-435. [CrossRef]

25. Ngai, S.; Ngai, T.; Vogel, F.; Story, W.; Thompson, G.B.; Brewer, L.N. Saltwater corrosion behavior of cold sprayed AA7075 aluminum alloy coatings. Corros. Sci. 2018, 130, 231-240. [CrossRef]

26. Wei, Y.K.; Li, Y.J.; Zhang, Y.; Luo, X.T.; Li, C.J. Corrosion resistant nickel coating with strong adhesion on AZ31B magnesium alloy prepared by an in-situ shot-peening-assisted cold spray. Corros. Sci. 2018, 138, 105-115. [CrossRef]

27. Zhang, Z.; Liu, F.; Han, E.H.; Xu, L. Mechanical and corrosion properties in 3.5\% NaCl solution of cold sprayed Al-based coatings. Surf. Coat. Technol. 2020, 385, 125372. [CrossRef]

28. Prando, D.; Brenna, A.; Diamanti, M.V.; Beretta, S.; Bolzoni, F.; Ormellese, M.; Pedeferri, M. Corrosion of titanium. Part 1: Aggressive environments and main forms of degradation. J. Appl. Biomater. Funct. Mater. 2017, 15, 291-302. [CrossRef]

29. Sun, J.; Han, Y.; Cui, K. Innovative fabrication of porous titanium coating on titanium by cold spraying and vacuum sintering. Mater. Lett. 2008, 62, 3623-3625. [CrossRef] 
30. Li, W.; Cao, C.; Yin, S. Solid-state cold spraying of Ti and its alloys: A literature review. Prog. Mater. Sci. 2020, $110,100633$. [CrossRef]

31. Morończyk, B.; Ura-Bińczyk, E.; Kuroda, S.; Jaroszewicz, J.; Molak, R.M. Microstructure and corrosion resistance of warm sprayed titanium coatings with polymer sealing for corrosion protection of AZ91E magnesium alloy. Surf. Coat. Technol. 2019, 363, 142-151. [CrossRef]

32. Zhang, D.; Wei, B.; Wu, Z.; Qi, Z.; Wang, Z. A comparative study on the corrosion behavior of Al, Ti, Zr and Hf metallic coatings deposited on AZ91D magnesium. Surf. Coat. Technol. 2016, 303, 94-102. [CrossRef]

33. ASTM E2109-01 Standard Test Methods for Determining Area Percentage Porosity in Thermal Sprayed Coatings; ASTM: West Conshohocken, PA, USA, 2014.

34. ASTM G133-05 Standard Test Method for Linearly Reciprocating Ball-on-Flat Sliding Wear; ASTM: West Conshohocken, PA, USA, 2005.

35. Menezes, P.L.; Nosonovsky, M.; Ingole, S.P.; Kailas, S.V.; Lovell, M.R. Tribology for Scientists and Engineers; Springer: Berlin, Germany, 2013.

36. Khun, N.W.; Tan AW, Y.; Liu, E. Mechanical and tribological properties of cold sprayed Ti coatings on Ti-6Al-4V substrates. J. Therm. Spray Technol. 2016, 25, 715-724. [CrossRef]

37. Siddique, S.; Li, C.X.; Bernussi, A.A.; Hussain, S.W.; Yasir, M. Enhanced Electrochemical and Tribo-logical Properties of AZ91D Mg Alloy via Cold Spraying of Al Alloy. J. Therm. Spray Technol. 2019, 28, 1739-1748. [CrossRef]

38. ASTM Standard G61-86 Standard Test Method for Conducting Cyclic Potentiodynamic Polarization (CPP) Measurements for Localized Corrosion Susceptibility of Iron-, Nickel-, or Cobalt-Based Alloys; ASTM: West Conshohocken, PA, USA, 2014.

39. Cizek, J.; Kovarik, O.; Siegl, J.; Khor, K.A.; Dlouhy, I. Influence of plasma and cold spray deposited titanium Layers on high-cycle fatigue properties of Ti6Al4V substrates. Surf. Coat. Technol. 2013, 217, 23-33. [CrossRef]

40. Sun, W.; Tan, A.W.Y.; Marinescu, I.; Toh, W.Q.; Liu, E. Adhesion, tribological and corrosion properties of cold-sprayed CoCrMo and Ti6Al4V coatings on 6061-T651 Al alloy. Surf. Coat. Technol. 2017, 326, 291-298. [CrossRef]

41. Sun, W.; Tan, A.W.Y.; Khun, N.W.; Marinescu, I.; Liu, E. Effect of substrate surface condition on fatigue behavior of cold sprayed Ti6Al4V coatings. Surf. Coat. Technol. 2017, 320, 452-457. [CrossRef]

42. Astarita, A.; Rubino, F.; Carlone, P.; Ruggiero, A.; Leone, C.; Genna, S.; Merola, M.; Squillace, A. On the Improvement of AA2024 Wear Properties through the Deposition of a Cold-Sprayed Titanium Coating. Metals 2016, 6, 185. [CrossRef]

43. Shi, Z.; Liu, M.; Atrens, A. Measurement of the corrosion rate of magnesium alloys using Tafel extrapolation. Corros. Sci. 2010, 52, 579-588. [CrossRef]

44. Liu, Y.; Meng, G.Z.; Cheng, Y.F. Electronic structure and pitting behavior of 3003 aluminum alloy passivated under various conditions. Electrochim. Acta 2009, 54, 4155-4163. [CrossRef]

45. Kumar, S.; Jyothirmayi, A.; Wasekar, N.; Joshi, S.V. Influence of annealing on mechanical and electrochemical properties of cold sprayed niobium coatings. Surf. Coat. Technol. 2016, 296, 124-135. [CrossRef]

46. Ezhilselvi, V.; Nithin, J.; Balaraju, J.N.; Subramanian, S. The influence of current density on the morphology and corrosion properties of MAO coatings on AZ31B magnesium alloy. Surf. Coat. Technol. 2016, 288, 221-229. [CrossRef]

47. Moreto, J.A.; Marino, C.E.B.; Bose Filho, W.W.; Rocha, L.A.; Fernandes, J.C.S. SVET, SKP and EIS study of the corrosion behavior of high strength Al and Al-Li alloys used in aircraft fabrication. Corros. Sci. 2014, 84, 30-41. [CrossRef]

48. Kendig, M.W.; Mansfeld, F. AC electrochemical impedance of a model pit. J. Electrochem. Soc. 1982, 129, C318.

49. Guo, F.; Jiang, W.; Tang, G.; Xie, Z.; Dai, H.; Wang, E.; Chen, Y.; Liu, L. Enhancing anti-wear and anti-corrosion performance of cold spraying aluminum coating by high current pulsed electron beam irradiation. Vacuum 2020, 182, 109772. [CrossRef]

50. Da Silva, F.S.; Bedoya, J.; Dosta, S.; Cinca, N.; Cano, I.G.; Guilemany, J.M.; Benedetti, A.V. Corrosion characteristics of cold gas spray coatings of reinforced aluminum deposited onto carbon steel. Corros. Sci. 2017, 114, 57-71. [CrossRef]

51. López-Ortega, A.; Arana, J.L.; Rodríguez, E.; Bayón, R. Corrosion, wear and tribo-corrosion performance of a thermally sprayed aluminum coating modified by plasma electrolytic oxidation technique for offshore submerged components protection. Corros. Sci. 2018, 143, 258-280. [CrossRef]

52. Lu, F.F.; Ma, K.; Li, C.X.; Yasir, M.; Luo, X.T.; Li, C.J. Enhanced corrosion resistance of cold-sprayed and shot-peened aluminum coatings on LA43M magnesium alloy. Surf. Coat. Technol. 2020, 394, 125865. [CrossRef]

53. Shi, Z.; Song, G.; Cao, C.N.; Lin, H.; Lu, M. Electrochemical potential noise of 321 stainless steel stressed under constant strain rate testing conditions. Electrochim. Acta 2007, 52, 2123-2133. [CrossRef]

54. Chen, L.; Gu, Y.; Liu, L.; Liu, S.; Hou, B.; Liu, Q.; Ding, H. Effect of ultrasonic cold forging technology as the pretreatment on the corrosion resistance of MAO Ca/P coating on AZ31B Mg alloy. J. Alloys Compd. 2015, 635, 278-288.

55. Liu, M.; Mao, X.; Zhu, H.; Lin, A.; Wang, D. Water and corrosion resistance of epoxy-acrylic-amine waterborne coatings: Effects of resin molecular weight, polar group and hydrophobic segment. Corros. Sci. 2013, 75, 106-113.

56. Daroonparvar, M.; Yajid, M.A.M.; Yusof, N.M.; Bakhsheshi-Rad, H.R. Preparation and corrosion resistance of a nanocomposite plasma electrolytic oxidation coating on $\mathrm{Mg}-1 \% \mathrm{Ca}$ alloy formed in aluminate electrolyte containing titania nano-additives. Alloys Compd. 2016, 68, 841-857. [CrossRef]

57. Daroonparvar, M.; Yajid, M.A.M.; Yusof, N.M.; Bakhsheshi-Rad, H.R.; Hamzah, E.; Mardanikivi, T. Deposition of duplex MAO layer/nanostructured titanium dioxide composite coatings on $\mathrm{Mg}-1 \% \mathrm{Ca}$ alloy using a combined technique of air plasma spraying and micro arc oxidation. Alloys Compd. 2015, 649, 591-605. [CrossRef] 
58. Bordbar-Khiabani, A.; Yarmand, B.; Sharifi-Asl, S.; Mozafari, M. Improved corrosion performance of biodegradable magnesium in simulated inflammatory condition via drug-loaded plasma electrolytic oxidation coatings. Mater. Chem. Phys. 2020, $239,122003$. [CrossRef]

59. Hu, J.; Li, Q.; Zhong, X.; Zhang, L.; Chen, B. Composite anticorrosion coatings for AZ91D magnesium alloy with molybdate conversion coating and silicon sol-gel coatings. Prog. Org. Coat. 2009, 66, 199-205. [CrossRef]

60. Sowa, M.; Simka, W. Electrochemical Impedance and Polarization Corrosion Studies of Tantalum Surface Modified by DC Plasma Electrolytic Oxidation. Materials 2018, 11, 545. [CrossRef]

61. Wang, C.; Fang, H.; Hang, C.; Sun, Y.; Peng, Z.; Wei, W.; Wang, Y. Fabrication and characterization of silk fibroin coating on APTES pretreated Mg-Zn-Ca alloy. Mater. Sci. Eng. C 2020, 110, 110742. [CrossRef]

62. Merl, D.K.; Panjan, P.; Kovač, J. Corrosion and surface study of sputtered Al-W coatings with a range of tungsten contents. Corros. Sci. 2013, 69, 359-368. [CrossRef]

63. Daroonparvar, M.; Khan, M.U.F.; Saadeh, Y.; Kay, C.M.; Kasar, A.K.; Kumar, P.; Esteves, L.; Misra, M.; Menezes, P.; Kalvala, P.R Modification of surface hardness, wear re-sistance and corrosion resistance of cold spray Al coated AZ31B Mg alloy using cold spray double layered $\mathrm{Ta} / \mathrm{Ti}$ coating in 3.5wt \% NaCl solution. Corros. Sci. 2020, 176, 109029. [CrossRef]

64. Cui, X.J.; Lin, X.Z.; Liu, C.H.; Yang, R.S.; Zheng, X.W.; Gong, M. Fabrication corrosion resistance of a hydrophobic micro- arc oxidation coating on AZ31 Mg alloy. Corros. Sci. 2015, 90, 402-412. [CrossRef]

65. Farooq, A.; Hamza, M.; Ahmed, Q.; Deen, K.M. Evaluating the performance of zinc and aluminum sacrificial anodes in artificial seawater. Electrochim. Acta 2019, 314, 135-141. [CrossRef]

66. Cui, L.Y.; Gao, S.D.; Li, P.P.; Zeng, R.C.; Zhang, F.; Li, S.Q.; Han, E.H. Corrosion resistance of a self-healing micro-arc oxidation/polymethyltrimethoxysilane composite coating on magnesium alloy AZ31. Corros. Sci. 2017, 118, 84-95. [CrossRef] 